\title{
Genomic Analysis of Endophytic Bacillus cereus T4S and Its Plant Growth-Promoting Traits
}

\author{
Bartholomew Saanu Adeleke (D), Ayansina Segun Ayangbenro (D) and Olubukola Oluranti Babalola * (D) \\ Food Security and Safety Niche Area, Faculty of Natural and Agricultural Sciences, North-West University, \\ Private Bag X2046, Mmabatho 2735, South Africa \\ * Correspondence: olubukola.babalola@nwu.ac.za; Tel.: +27-(0)1-8389-2568
}

Citation: Adeleke, B.S.; Ayangbenro, A.S.; Babalola, O.O. Genomic

Analysis of Endophytic Bacillus cereus T4S and Its Plant Growth-Promoting Traits. Plants 2021, 10, 1776. https:// doi.org/10.3390/plants10091776

Academic Editors: Umesh K. Reddy, Suhas Shinde, Padma Nimmakayala and Purushothaman Natarajan

Received: 8 July 2021

Accepted: 25 July 2021

Published: 26 August 2021

Publisher's Note: MDPI stays neutral with regard to jurisdictional claims in published maps and institutional affiliations.

Copyright: (C) 2021 by the authors Licensee MDPI, Basel, Switzerland. This article is an open access article distributed under the terms and conditions of the Creative Commons Attribution (CC BY) license (https:// creativecommons.org/licenses/by/ $4.0 /)$.

\begin{abstract}
Insights into plant endophytic microbes and their exploration in agriculture have provided opportunities for sustainable plant health and food safety. Notable endophytic Bacillus species with plant growth-promoting traits have been documented; nevertheless, information on genome analysis of B. cereus associated with the sunflower in South Africa has not been studied. Therefore, we present whole-genome sequence of agriculturally important $B$. cereus strain T4S isolated from sunflower plants. The NextSeq Illumina sequencing yielded 7,255,762 bp sequence reads, $151 \mathrm{bp}$ average read length, 5,945,881 bp genome size, 56 tRNA, 63 rRNA, and G + C content of 34.8\%. The phylogeny analysis of strain T4S was similar to B. cereus NJ-W. Secondary metabolites, such as petrobactin, bacillibactin, bacitracin, molybdenum factor, zwittermicin, and fengycin underlining bacterial biocontrol efficacy against phytopathogens were found in the T4S genome. The predicted novel genes in the bacterial genome mediating the complex metabolic pathways can provide a genetic basis in understanding endosphere biology and their multiple functions thereof in crop improvement. Interestingly, seed and root inoculation with strain T4S contributed to sunflower yield under greenhouse experiments. Hence, the detection of notable genes specific for plant growth promotion as validated under in vitro screening, promisingly, suggests the relevance of strain T4S in agricultural biotechnology.
\end{abstract}

Keywords: bacterial endophytes; greenhouse experiment; Illumina sequencing; oilseed crop; plant growth promotion; secondary metabolite genes

\section{Introduction}

In recent times, agricultural sustainability to maximally meet the nutritional food demand of the growing population needs a boost, more importantly, to avert future food scarcity and insecurity, and hunger. Notably, one of the promising measures is through agricultural intensification and research innovations into biotechnological functions of agriculturally important microbes inhabiting the endosphere of crops and how they can be explored as bioinoculants on a commercial scale [1,2].

Agricultural practices such as tillage, crop rotation, and fertilizer application contribute to food production, reduce pest re-insurgence, and plant-pathogen attack [3]. This has also ensured the availability of quantity and quality of food products for human beings [4]. However, the incessant use of agrochemicals by farmers to recover the essential nutrient loss in the soil for crop improvement has continually harmed the environment $[5,6]$. It has been postulated that indiscriminate or continuous use of agrochemicals does not have linkage to the quantity of food produced per annum, instead, it leads to negative environmental stimuli and consequences, particularly water contamination and pollution problems [7].

To mitigate these threats, employing best and acceptable practices to reduce the rate of chemical fertilization to enhance crop production remains fundamental to sustainable agriculture. These measures include harnessing endophytic bacteria as invaluable resources in exchange for agrochemicals to improve plant resistance against biotic and abiotic 
stresses [8]. Conversely, price instability, scarcity, and limited supply of chemical fertilizers due to the energy crisis, political, economic, and natural disasters can influence the rate of food production. In ecologically threatened regions, the plant is faced with a lot of stress adaptors, thus instigating their internal and physiological cellular responses [9]. Nevertheless, the recruitment of endophytic microbes as biological adjuvants to support plant growth in harsh or drought-prone areas can stimulate adaptive immune responses in plants [10].

Furthermore, employing endophytic bacteria as bio-factory in the synthesis of certain secondary metabolites can enhance their efficacy in agricultural biotechnology and implementation [11]. Endophytes are microorganisms that inhabit the internal tissue of the host plants without causing disease symptoms [12]. The mechanistic effects of these bacteria on plant growth-promotion can be direct or indirect. Significantly, plant growth-promoting endophytes (PGPE) support plants in diverse ways, mainly in the induction of systemic resistance, synthesis of phytohormones, antibiosis on phytopathogens, and competition for available nutrient and water in an ecological niche [13].

Based on the dominance of the genera Bacillus in different environments, their contributions to enhancing plant growth cannot be overemphasized. Additionally, their singularly or combined inoculation has shown significant effects on crop (wheat) yield compared to the un-inoculated $[7,14]$. The improvement in plant biomass and crop yields, such as rice, Arabidopsis, wheat, maize, sorghum, and soybean upon inoculation with PGPE as demonstrated, has enhanced their productivity [7,15]. Igiehon et al. [16] have reported an inconsistent and less effect of a single bacterial application on experimental plants. Nevertheless, co-inoculation of non-antagonistic bacteria is found significant, contributing to plant performance in terms of quality and quantity than single inoculation. Notwithstanding, Subramanian et al. [17] and Ríos-Ruiz et al. [18] have reported an improvement in the yield of soybean co-inoculated with endophytic Bradyrhizobium japonicum and Bacillus megaterium and rice yields inoculated with endophytic Burkholderia ubonensis, Citrobacter bitternis, and Burkholderia vietnamiensis, respectively.

The group of bacterial species in the genus Bacillus can be found in various ecosystems, based on the endospore attributes that make them persist in extreme environments [19]. The multiple functional attributes of endophytic bacteria in agriculture can underline their potential based on the expression of novel genes in the bacterial genome that is involved in various metabolic pathways. For example, sulfur metabolism, phytohormone, exopolysaccharide, siderophore synthesis, enzyme biosynthesis, tryptophan metabolism, nitrogen fixation, and photosynthesis [20].

The discovery of vital genes in Bacillus isolated from sunflower can make them suitable candidates for various biotechnological applications. Significantly, bacterial inoculation of economically relevant plants, such as sunflower, can contribute to growth and oil production. Sunflower is classified as one of the leading oilseed crops after soybean, safflower, and rapeseed, especially in South Africa [4]. Despite the economic importance of sunflower and the identification of B. cereus from other plants [14], little information is available on the genome analysis of $B$. cereus associated with the root of sunflower in South Africa. $B$. cereus is a Gram-positive, spore-forming, rod-like bacterium belonging to the Bacillus genus. The whole-genome sequencing of $B$. cereus isolated from the rhizosphere and endosphere of plants has revealed notable genes in their genome, more importantly, plant growth-promoting genes [21,22]. In addition, Hong et al. [23] have reported the complete genome sequence of endophytic bacterium B. cereus strain PgBE311 isolated from Panax ginseng. However, reports on the B. cereus isolated from the sunflower are less documented, thus suggesting its exploration and application in improving crop yield. Sunflower yield can be improved depending on the efficacy of the copious associated bacterial endophytes upon inoculation under experimental conditions. Therefore, we report the isolation, cultured-based screening of plant growth-promoting traits, and genomic characterization of endophytic bacterium B. cereus T4S isolated from sunflower root endosphere, and its effect on sunflower yield under greenhouse experiment. 


\section{Results}

\subsection{Biochemical and Cultural Features}

The biochemical and cultural characterization of B. cereus T4S is presented in Table S1. The results indicated that $B$. cereus T4S is rod-like, catalase-positive, and Gram-positive. The strain T4S assimilates all the tested sugars and exhibited a positive reaction to citrate, oxidase, nitrate, casein, and starch hydrolysis. Furthermore, strain T4S grows between $\mathrm{pH}$ ranging from 4 to 10 , temperature from 25 to $45^{\circ} \mathrm{C}$, and $5.5 \%$ normal saline. The results of plant growth-promoting tests were high, with a siderophore value of $87.30 \%$, phosphate content of $30.43 \mu \mathrm{g} / \mathrm{mL}$, and IAA of $11.28 \mu \mathrm{g} / \mathrm{mL}$, respectively (Table 1). Bacterial endophytes exhibited significant reactions for protease, xylanase, mannanase, and cellulase production, except amylase during enzyme plate assay. The phylogeny of the genome sequence of B. cereus strain T4S is presented in Figure 1.

Table 1. Plant growth-promoting features of B. cereus T4S.

\begin{tabular}{|c|c|c|c|c|c|}
\hline Test & \multicolumn{5}{|c|}{ Plant Growth-Promoting Traits } \\
\hline & IAA $(\mu \mathrm{g} / \mathrm{mL})$ & Siderophore (\%) & Phosphate $(\mu \mathrm{g} / \mathrm{mL})$ & Exopolysaccharide & \\
\hline Qualitative & + & ++ & + & ++ & \\
\hline Quantitative & $11.29 \pm 0.01^{a}$ & $87.30 \pm 0.38^{c}$ & $30.43 \pm 0.18^{b}$ & ND & \\
\hline Test & \multicolumn{5}{|c|}{ Enzyme Assay } \\
\hline & Amylase & Cellulase & Xylanase & Mannanase & Protease \\
\hline Qualitative & - & ++ & ++ & ++ & + \\
\hline $\mathrm{ZOC}(\mathrm{mm})$ & $0 \pm 0.00^{\mathrm{a}}$ & $50.00 \pm 0.01^{\mathrm{d}}$ & $180.00 \pm 0.01^{\mathrm{e}}$ & $35.00 \pm 0.01^{c}$ & $4.00 \pm 0.01^{b}$ \\
\hline
\end{tabular}

Key: $-=$ negative reaction, $+=$ positive reaction, ZOC-zone of clearance measurement, ND-not determined. Values are represented as mean \pm standard deviation of triplicate readings. The superscript (small letters) within the same row represent a significant difference.

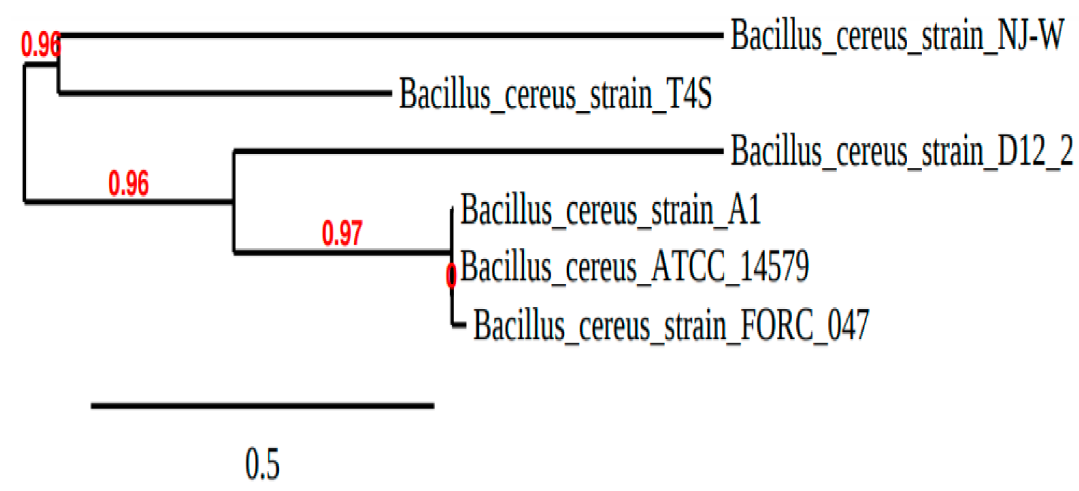

Figure 1. Phylogeny of the genome sequence data of B. cereus T4S. Legend: Scheme 0 . means $96 \%$ difference between two bacterial sequences.

\subsection{Whole Genome Sequencing Analysis}

The WGS analysis of $B$. cereus T4S yielded a sequence read count of 7,255,762, a genome size of $5,945,881 \mathrm{bp}$, total bases of $109,562,062$, and $\mathrm{G}+\mathrm{C}$ content of $34.8 \%$. The read length mean was $151 \mathrm{bp}$ while $L_{50}$ and $N_{50}$ values were 32 and $65,078 \mathrm{bp}$, respectively. The number of contigs and subsystems was 198 and 341, respectively. The genome analysis revealed 6277 coding sequences and 63 RNAs. The circular genome visualization of B. cereus strain T4S is represented in Figure 2. The subsystem statistics show 27 subsystem feature counts of the coding protein into functional groups based on the annotated genome classification by SEED in RAST. The functional basis of 5159 protein-coding genes (PCG) was assessed from the KEGG database and RAST online server. The 1961 genes annotated by SEED viewer (version 2.0) were grouped into molecular function, cellular components, and biological processes. The topmost five groups were protein metabolism (155 genes), vitamins, prosthetic groups, pigments (161 genes), cofactor, amino acids and derivatives (377 genes), carbohydrates (271 genes), and nucleosides and nucleotides (119 genes). 
The PCG from the genome of strain T4S revealed various genes involved in biocontrol, biomolecule transport and degradation, metabolic pathway, and synthesis of cellular components. Moreover, their locus tag, specific gene type, and gene product (Tables 2-5, Tables S2-S13). In Table S2, various secretion systems genes are highlighted. It was revealed that $B$. cereus T4S harbors nitrogen fixation genes (nif $U$ and nif3-like) and other genes involved in ammonia and urea transport, nitrogen metabolism, nitrogen regulation, and nitrate reduction pathway (Table 2).

Table 2. Genes involved in nitrogen fixation and nitrogen metabolism.

\begin{tabular}{|c|c|c|c|}
\hline Pathway & Gene & Product & Locus Tag \\
\hline \multirow{5}{*}{ Nitrogen fixation } & & & HWX41_RS02785/ \\
\hline & nif3- & nitrogen fixation protein Nif3-like & HWX41_RS08235/ \\
\hline & & & HWX41_RS00530 \\
\hline & nif $\mathrm{U}$ & nitrogen fixation protein NifU & HWX41_RS22890 \\
\hline & nif & Flavodoxin & HWX41_RS17075 \\
\hline \multirow[t]{5}{*}{ Nitrogen metabolism } & $g l t \mathrm{P}$ & glutamate/aspartate: proton symporter GltP & HWX41_RS16800 \\
\hline & glt $\mathrm{X}$ & Glutamate-tRNA ligase & HWX41_RS26220 \\
\hline & $g \ln R$ & transcriptional repressor $G \ln \mathrm{R}$ & HWX41_RS05880 \\
\hline & $g \ln \mathrm{A}$ & type I glutamate-ammonia ligase/glutamine & HWX41_RS05885 \\
\hline & $g \ln \mathrm{H}$ & ABC transporter substrate-binding protein $G \ln \mathrm{H}$ & HWX41_RS23555 \\
\hline Nitrogen regulation & nadR & transcription repressor $N a d R$ & HWX41_RS02105 \\
\hline \multirow{8}{*}{$\begin{array}{l}\text { Dissimilatory nitrate } \\
\text { reduction }\end{array}$} & nirB & nitrite reductase (NADH) large subunit & HWX41_RS13635 \\
\hline & $\operatorname{nir} \mathrm{D}$ & nitrate reductase (NADH) small subunit & HWX41_RS13640 \\
\hline & narI & respiratory nitrate reductase subunit gamma & HWX41_RS13700 \\
\hline & $\mathrm{NarH}$ & nitrate reductase subunit beta/nitrate reductase & HWX41_RS13710 \\
\hline & narJ & molybdenum cofactor assembly chaperone & HWX41_RS13705 \\
\hline & nar & nitrate reductase subunit alpha & HWX41_RS13715 \\
\hline & nar & nitrate reductase & HWX41_RS13945 \\
\hline & nark & nitrate transporter & HWX41_RS13665 \\
\hline \multirow[t]{2}{*}{ Ammonia assimilation } & $g l t X$ & glutamate-tRNA ligase & HWX41_RS26220 \\
\hline & gltP & glutamate/aspartate: proton symporter GltP & HWX41_RS16800 \\
\hline
\end{tabular}

Table 3. Genes Involved in Phosphate Solubilization and Transport.

\begin{tabular}{|c|c|c|c|}
\hline Pathway & Gene & Product & Locus Tag \\
\hline \multirow{4}{*}{$\begin{array}{l}\text { Degradation of } \\
\text { phosphonates }\end{array}$} & $p h n C$ & phosphonate transport system ATP-binding & HWX41 RS05935 \\
\hline & phnF & $\begin{array}{l}\text { phosphonate metabolism transcriptional regulator phnF } \\
\text { phosphonate transport system permease protein }\end{array}$ & HWX41_RS04040 \\
\hline & phnE & phosphonate transport system permease protein & HWX41_RS05940/HWX41_RS05945 \\
\hline & $i s p \mathrm{H}$ & 4-hydroxy-3-methylbut-2-enyl diphosphate reductase & HWX41_RS02790 \\
\hline \multirow[t]{10}{*}{ Phosphate transport } & phn & $\begin{array}{c}\text { phosphate/phosphite/phosphonate ABC transporter } \\
\text { substrate-binding protein }\end{array}$ & HWX41_RS05930 \\
\hline & pstC & phosphate transport system permease & HWX41_RS23195 \\
\hline & pstS & phosphate transport system substrate-binding protein & HWX41_RS02875/HWX41_RS23200 \\
\hline & pstS & phosphate transport system substrate-binding protein & HWX41_RS02870 \\
\hline & pstB & phosphate transport system ATP-binding protein & HWX41_RS02885 \\
\hline & pstA & phosphate transport system permease protein & HWX41_RS23190/HWX41_RS02880 \\
\hline & phoU & phosphate signaling complex protein $\mathrm{PhoU}$ & HWX41_RS02890 \\
\hline & gltP & glycerol-3-phosphate transporter & HWX41_RS23465 \\
\hline & ugpC & $\begin{array}{c}\text { sn-glycerol-3-phosphate } \mathrm{ABC} \text { transporter ATP-binding } \\
\text { protein } U_{g p} \mathrm{C}\end{array}$ & HWX41_RS04235/HWX41_RS23895 \\
\hline & phoH & $\begin{array}{c}\text { phosphate starvation-inducible protein } \mathrm{PhoH} \text { and } \\
\text { related proteins }\end{array}$ & HWX41_RS02710 \\
\hline
\end{tabular}


Table 4. Genes involved in iron transport and siderophore production.

\begin{tabular}{cccc}
\hline Pathway & Gene & Product & Locus Tag \\
\hline Iron(III) transport & $f b p \mathrm{~A}$ & fur-regulated basic protein FbpA & HWX41_RS15335/HWX \\
Iron(II) transport & $f e t \mathrm{~B}$ & $\begin{array}{c}\text { ferrous iron transport protein A } \\
\text { iron export ABC transporter }\end{array}$ & HWX41_RS00335 \\
& $f e t \mathrm{~B}$ & $\begin{array}{c}\text { permease subunit FetB } \\
\text { ferrous iron transport protein B }\end{array}$ & HWX41_RS22925 \\
& $f e o \mathrm{~B}$ & HWX41_RS00340 \\
Siderophore transport & $f e t \mathrm{~B}$ & $\begin{array}{c}\text { siderophore ABC transporter } \\
\text { substrate-binding protein }\end{array}$ & HWX41_RS24585 \\
\hline
\end{tabular}

Table 5. Genes involved in the modulation of plant hormones.

\begin{tabular}{|c|c|c|c|}
\hline Pathway & Gene & Product & Locus Tag \\
\hline ACC catabolism & $\operatorname{acdA}$ & acyl-CoA dehydrogenase $A c d \mathrm{~A}$ & HWX41_RS21030 \\
\hline $\begin{array}{l}\text { Potassium transport } \\
\text { L-tryptophan }\end{array}$ & $k d p \mathrm{~A}$ & potassium-transporting ATPase subunit A & HWX41_RS15255 \\
\hline \multirow{6}{*}{$\begin{array}{l}\text { production; IAA } \\
\text { production }\end{array}$} & ND & tryptophan synthase subunit alpha & HWX41_RS17780 \\
\hline & $\operatorname{trp} \mathrm{B}$ & tryptophan synthase subunit beta & HWX41_RS17785 \\
\hline & $\operatorname{trpC}$ & indole-3-glycerol phosphate synthase $\operatorname{Tr} p \mathrm{C}$ & HWX41_RS17795 \\
\hline & $\operatorname{trp} \mathrm{D}$ & anthranilate phosphoribosyltransferase & HWX41_RS17800 \\
\hline & $\operatorname{trp} \mathrm{E}$ & anthranilate synthase component I & HWX41_RS17810 \\
\hline & $\operatorname{trpS}$ & Tryptophan-tRNA ligase & HWX41_RS18055 \\
\hline \multirow{10}{*}{$\begin{array}{l}\text { IAA production, IPA } \\
\text { pathway }\end{array}$} & dhaS & aldehyde dehydrogenase DhaS & HWX41_RS06485 \\
\hline & dha & aldehyde dehydrogenase & HWX41_RS25615 \\
\hline & dha & acetaldehyde dehydrogenase (acetylating) & HWX41_RS13995 \\
\hline & dha & aldehyde dehydrogenase family protein & HWX41_RS19325 \\
\hline & dha & aldehyde dehydrogenase family protein & HWX41_RS06850 \\
\hline & dha & aldehyde dehydrogenase family protein & HWX41_RS10480 \\
\hline & dha & aldehyde dehydrogenase family protein & HWX41_RS13000 \\
\hline & dha & aldehyde dehydrogenase family protein & HWX41_RS17225 \\
\hline & dha & aldehyde dehydrogenase family protein & HWX41_RS17590 \\
\hline & dha & aldehyde dehydrogenase family protein & HWX41_RS14005 \\
\hline $\begin{array}{l}\text { CK biosynthesis and } \\
\text { transformation }\end{array}$ & miaA & $\begin{array}{l}\text { (adenosine(37)-N6)-dimethylallyltransferase } \\
\text { MiaA }\end{array}$ & HWX41_RS05835 \\
\hline Ammonia production & $\operatorname{nad} \mathrm{E}$ & ammonia-dependent NAD(+) synthetase & HWX41_RS14365 \\
\hline
\end{tabular}

Key: ND—not determined.

The presence of PCG involved in the degradation of phosphonates such as phnCE and is $p \mathrm{E}$, and phosphate transport (pst $\mathrm{ABCS}$, phoUH, gltP, and $u g p \mathrm{C}$ ) in B. cereus T4S is shown in Table 3. Similarly, the genes mediating sulfate transport were detected in the genome of B. cereus T4S (Table S3). B. cereus T4S possesses genes involved in iron transport and siderophore production, which include, $f b p \mathrm{~A}, f e o \mathrm{AB}$, and $f e t \mathrm{~B}$ (Table 4). Several other genes responsible for flagellar biosynthesis (flgBDEGK, flhABG, fliCEFKLMNPQRSY, and motAB), chemotaxis (cheVW), and biofilm formation ( $e f p, h f q$, and $c r p$ ) were detected in B. cereus T4S (Table S4). Other genes that mediate lipopolysaccharide biosynthesis were also detected in strain T4S (Table S5). Genes involved in the degradation of superoxide anion radicals and hydrogen peroxide ( $\operatorname{sod} \mathrm{A}$ and $k a t \mathrm{~B})$, as well as gene $a h p \mathrm{C}$ coding for peroxiredoxin, were detected in the genome of B. cereus T4S (Table S6). Other related genes involved in carbohydrate metabolism and transport, organic acid metabolism, amino acid degradation and transformation, opine and GABA transport and metabolism, lignin degradation and degradation against toxic peroxides, and modulation of plant hormones are presented in Table 5 and Tables S7-S12.

Subsequently, identifiable genes specific for biological control such as isoprene (isp G), colonization ( $\min \mathrm{D}), 2,3$-butanediol (ilvABCDEGN), and volatile degradation (acoAB) pathways were identified in the genome of B. cereus T4S (Table S13). 


\subsection{Predicted Secondary Metabolite Cluster Genes by antiSMASH}

Table 6 shows the predicted secondary metabolite cluster genes from antiSMASH analysis of B. cereus T4S. Six notable secondary metabolite cluster genes detected include regulatory genes, other genes, additional biosynthetic genes, core biosynthetic genes, resistance genes, and transport-related genes (Figure 3a,b). B. cereus T4S exhibited 100\% similarity for gene type siderophore and non-ribosomal peptides (NRPS), with the most similar known cluster for petrobactin and bacitracin (Table 6). The siderophore-and-NRPSencoding genes in B. cereus T4S were found in the location between 28,853 and 42,560 nt. (total: $13,708 \mathrm{nt}$ ) as well as 1 and 57,852 nt. (total: 57,852 nt) of the entire genomic region. 
Table 6. Estimate of secondary metabolite genes in genome of B. cereus T4S.

\begin{tabular}{|c|c|c|c|c|c|c|}
\hline Node Rg & From & To & MSKC & & Type & Similarity \\
\hline $\operatorname{Rg} 1.1$ & 28,953 & 42,560 & Petrobactin & Other & Siderophore & $100 \%$ \\
\hline $\operatorname{Rg} 3.1$ & 93,263 & 140,279 & & & NRPS & \\
\hline $\operatorname{Rg} 3.2$ & 155,248 & 165,496 & & & RiPP-like & \\
\hline $\operatorname{Rg} 21.1$ & 20,448 & 75,995 & & & NRPS & \\
\hline $\operatorname{Rg} 28.1$ & 22,582 & 65,892 & Bacillibactin & NRP & NRPS & $46 \%$ \\
\hline $\operatorname{Rg} 35.1$ & 1 & 57,852 & Bacitracin & NRP & NRPS & $100 \%$ \\
\hline $\operatorname{Rg} 42.1$ & 16,640 & 38,493 & Molybdenum cofactor & Other & Terpene & $17 \%$ \\
\hline $\operatorname{Rg} 46.1$ & 1 & 45,939 & Zwittermicin A & NRP + Polyketide & NRPS, T1PKS & $77 \%$ \\
\hline $\operatorname{Rg} 62.1$ & 5236 & 34,100 & & & NRPS-like & \\
\hline $\operatorname{Rg} 71.1$ & 8999 & 19,310 & & & RiPP-like & \\
\hline $\operatorname{Rg} 86.1$ & 1 & 23,433 & & & NRPS & \\
\hline $\operatorname{Rg} 87.1$ & 1 & 17,771 & & & LAP, RiPP-like & \\
\hline $\operatorname{Rg} 89.1$ & 1 & 22,451 & Zwittermicin A & NRP + Polyketide & NRPS, T1PKS & $7 \%$ \\
\hline $\operatorname{Rg} 91.1$ & 7584 & 22,279 & Fengycin & NRP & Betalactone & $20 \%$ \\
\hline
\end{tabular}

Key: MSKC—Most similar known cluster, Rg—region, NRPS—nonribosomal peptides, NRP—nonribosomal peptide, T1PKS—type 1 polyketide synthases, LAP—lantipeptide, RiPP—ribosomally synthesized and post-translationally modified peptide.
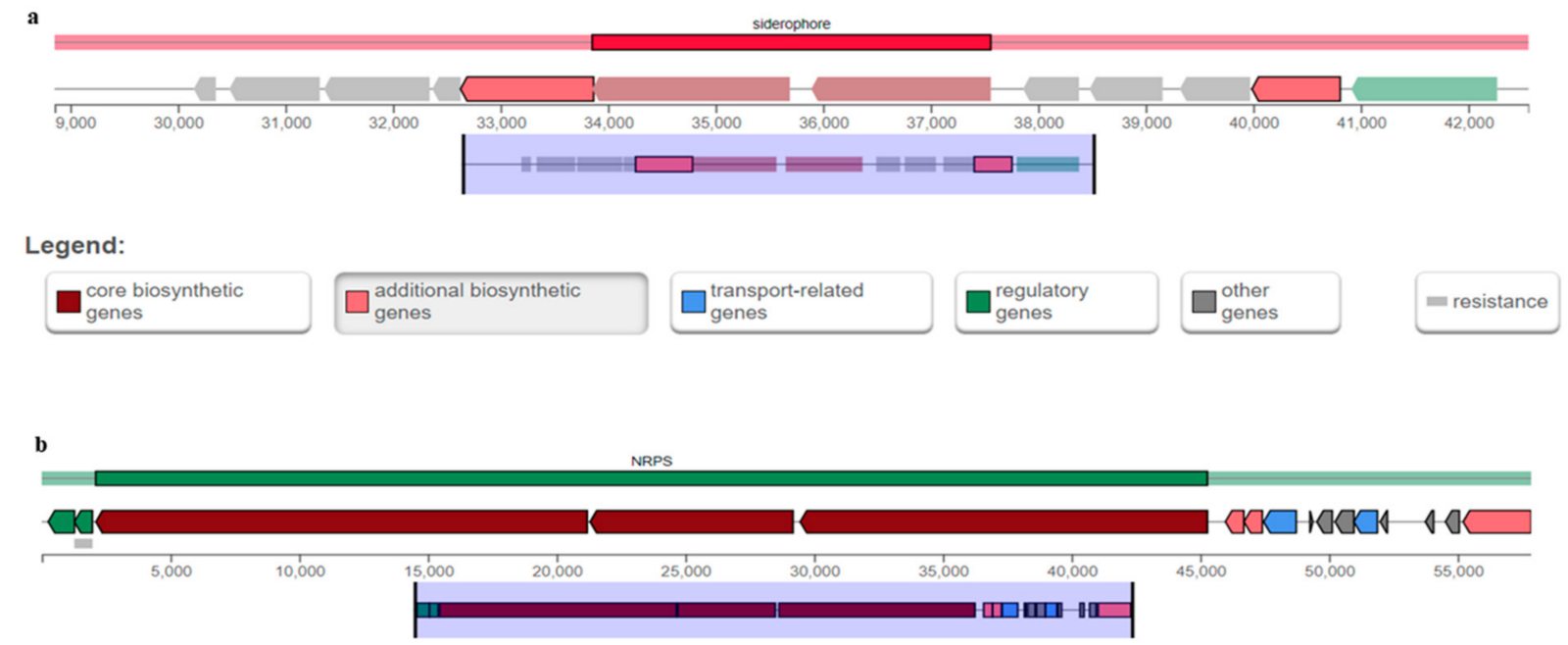

Legend:

$\square$ genes

Figure 3. (a,b): Graphical representation of siderophore-and-nonribosomal peptide (NRPS)-encoding genes. These loci are predicted from the whole genome assembly of B. cereus T4S.

\subsection{Effect of Bacterial Inoculation on Sunflower Yield}

The resulting output from the greenhouse experiment is presented in Table 7. Inoculated sunflower with B. cereus T4S statistically was significantly different in the growth parameter compared to non-inoculated (Figure 4). Here, the results show higher yields in the parameters measured in the inoculated plant than un-inoculated, except for the seed dry weight with no significant difference. The physical and chemical analysis of the soil sample recorded high magnesium content, $642(\mathrm{mg} / \mathrm{kg})$, followed by potassium content, $399(\mathrm{mg} / \mathrm{kg})$, and the least value $0.10 \%$ of total nitrogen content (Table S14). The clay, sand, and silt values were $22.20 \%, 68.30 \%$, and $7.92 \%$, respectively. 
Table 7. Sunflower Yield Parameters.

\begin{tabular}{|c|c|c|c|}
\hline Level & Growth Parameter & Non-Inoculated & $\begin{array}{l}\text { Inoculated with } \\
\text { B. cereus } \mathrm{T} 4 \mathrm{~S}\end{array}$ \\
\hline \multirow[t]{7}{*}{ Belowground } & Tap root length $(\mathrm{cm})$ & $146.67 \pm 58.33^{\mathrm{a}}$ & $158.33 \pm 40.20^{b}$ \\
\hline & Tap root width $(\mathrm{cm})$ & $5.33 \pm 0.58^{\mathrm{a}}$ & $7.00 \pm 1.00^{b}$ \\
\hline & Root length (cm) & $217 \pm 81.22^{\mathrm{a}}$ & $339.67 \pm 82.78^{b}$ \\
\hline & Lateral root number & $25.67 \pm 1.53^{\mathrm{a}}$ & $29.67 \pm 1.53^{b}$ \\
\hline & Root wet weight (g) & $44.09 \pm 16.12^{\mathrm{a}}$ & $65.54 \pm 18.41^{b}$ \\
\hline & Root dry weight (g) & $8.41 \pm 1.55^{\mathrm{a}}$ & $11.43 \pm 5.44^{b}$ \\
\hline & Number of roots & $935 \pm 11.30^{\mathrm{a}}$ & $1209.67 \pm 348.26^{b}$ \\
\hline \multirow[t]{7}{*}{ Aboveground } & Seed wet weight (g) & $0.05 \pm 0.01^{\mathrm{a}}$ & $0.25 \pm 0.33^{b}$ \\
\hline & Seed dry weight (g) & $0.03 \pm 0.01^{\mathrm{a}}$ & $0.035 \pm 0.00^{\mathrm{a}}$ \\
\hline & Head fresh weight $(\mathrm{g})$ & $153.76 \pm 13.94^{\mathrm{a}}$ & $165.50 \pm 7.55^{b}$ \\
\hline & Head dry weight (g) & $41.55 \pm 4.27^{\mathrm{a}}$ & $45.92 \pm 13.33^{b}$ \\
\hline & $\begin{array}{l}\text { Plant wet weight dry } \\
\qquad(\mathrm{g})\end{array}$ & $331.04 \pm 20.16^{\mathrm{a}}$ & $392.69 \pm 8.70^{b}$ \\
\hline & Shoot wet weight (g) & $165.82 \pm 5.16^{\mathrm{a}}$ & $183.55 \pm 13.75^{b}$ \\
\hline & Shoot dry weight (g) & $57.28 \pm 7.04^{\mathrm{a}}$ & $68.24 \pm 22.13^{b}$ \\
\hline
\end{tabular}

Values are represented as means \pm standard deviation of triplicate readings. The superscript (small letters) within the same column represent a significant difference.
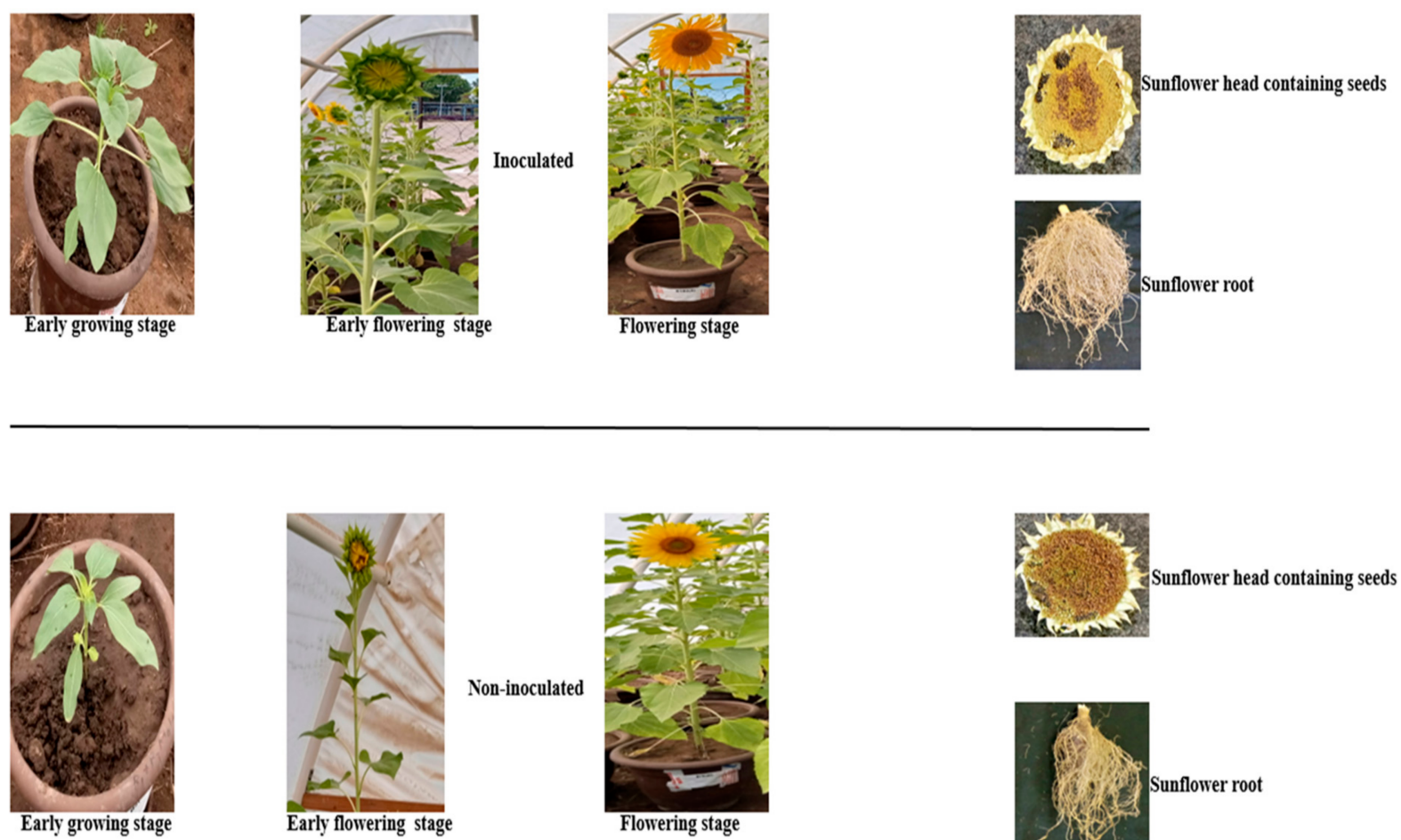

Figure 4. Inoculated and non-inoculated sunflower growth and yield parameters.

\section{Discussion}

In recent times, the potential of microbial endophytes ranging from plant growth promotion to control of phytopathogens to ensure agriculture sustainably remains fundamental [24]. Significantly, the detection of multifunctional genes from the diverse bacterial community in the roots endosphere by whole genome sequence analysis with biotechnological prospecting has provided salient information on the metabolic activities and their agricultural importance [25]. Nevertheless, this approach has gainfully acquitted researchers with a motivational framework in the exploration of environmental microbes as a key bio-factory of various compounds, importantly for both present and future use. 
Biotechnologically, the accumulated information on less studied endophytic microbes in the sunflower endosphere would significantly necessitate more research, focusing on plant beneficial bacterial endophytes with multifaceted metabolic potential. To this premise and based on scanty information relating to the whole genome analysis of endophytic bacteria in the sunflower root endosphere (SRE), we present this research as a promising genomic overview into SRE biology.

The genomic sequence dataset of B. cereus strain T4S from the SRE was analyzed. The identified strain T4S potentially produces lytic enzymes, IAA, siderophores, and also, displayed the ability to solubilize phosphate. To corroborate this, research findings into plant growth-promoting activities of endophytic bacteria colonizing the root endosphere of sunflower based on their multifunctional traits could functionally ensure better crop yields [26].

The genomic insights into B. cereus T4S might perhaps unravel its diverse bioprospecting abilities, channeling appropriate specific mechanisms of action in the host plants. The abundance of exudates in the root environment can facilitate rhizobacteria infiltrating from the external root environment into the root endosphere and become endophytes [27]. Notably, exudate secretions from the plant roots can enhance bacterial colonization and establishment of plant-microbes equilibrium in the root endosphere, thus significantly improve plant performance [28]. Bacterial root colonization has been attributed to the presence of specific genes involved in biofilm formation, chemotaxis, and flagellation in their genome, thus enabling them to establish a bacterial community in the plant endosphere with multiple functions to promote plant growth under water-deficit stress. The phylogeny analysis of the genome sequence of $B$. cereus $\mathrm{T} 4 \mathrm{~S}$ revealed a close relatedness to $B$. cereus $\mathrm{NJ}-\mathrm{W}$. The positioning of taxonomic classification of bacteria can be resolved based on gene sequences.

The detection of several genes involved in protein secretion systems and TAT pathways is presented in this study. Peptidase could mediate the export of protein by cleaving the $\mathrm{N}$-terminal of a signal peptide. Secretions of complex genes such as $\sec \mathrm{Y}, \sec \mathrm{E}, \sec \mathrm{D}, \sec \mathrm{G}$, and secF in the cytoplasm of bacteria are known [29]. The presence of SecA in most bacteria facilitates the binding of signal peptides as a driver in the translocation of protein through other gene channels, like secYEG. Moreover, secB in the cytoplasm could contribute to protein stability and secretion within the cell. Exhibition of oxidative gene encoding pyrroloquinoline quinone (PQQ)-dependent sugar dehydrogenase by strain T4S could be an indication of bacterial resistance or adaptation to reactive oxygen species (ROS) produced under a stress-induced environment in building strong defense mechanisms in the host plants [30,31].

The presence of nitrogen fixation genes, nif3-like and nif $\mathrm{U}$ by strain T4S revealed that they can participate effectively in biological nitrogen fixation through the conversion of dinitrogen gas into nitrate and ammonium within the plant tissues. The biological nitrogen fixation by Bacillus spp. in chicken-pea grown in nitrogen-deficient soil environment has been reported [32]. Recently, the identification of nif $\mathrm{U}$ in P. aeruginosa B8 isolated from the root of sugar with nitrogen fixation potential has been documented [25]. Phosphorus is either fixed or immobilized in the soil, thus limiting its usage by plants. Phosphorus is made available to plants by phosphate-solubilizing microorganisms, especially the endophytic type capable of synthesizing phosphatases and organic acids [11]. Different Bacillus strains such as B. pumilis, B. subtilis, B. amyloliquenfaciens, and B. methylotrophicus are regarded as phosphate solubilizers, and their use in soil management has enhanced phosphorus level in soil $[33,34]$. The screened genome of strain T4S uncovered genes involved in phosphonate degradation and phosphate transport pathways. Various genes involved in phosphate solubilization and transport include $p h b \mathrm{CEF}, i s p \mathrm{H}, p s t \mathrm{ABCS}, p h o \mathrm{U}$, $g l t \mathrm{P}$, and $u g p \mathrm{C}$. The presence of $p s t$ encoding phosphate transport system permease protein as predicted can be accountable for an increase in phosphate uptake and bioavailability in a phosphate-limiting environment [30], thus contributing to plant growth. The role of $p s t$ in the phosphate transport pathway by B. subtilis MBI 600, B. cereus 905, and Paenibacillus 
polymyxa HK4 has been documented [22,29,35]. Notably, the detection of phosphate transport genes (pstABCS) correlates with the finding of Zeng, $\mathrm{Xie}, \mathrm{Li}, \mathrm{Gao}, \mathrm{Xu}$, and Wang [22], who reported the same genes in the whole genome of plant growth-promoting $B$. cereus strain 905. Similarly, Singh et al. (2021) have reported the presence of phosphate transport genes (pstABCS) in the genome of P. aeruginosa B18. Nevertheless, the authors have also reported phoBDHR, which was not detected in this study. In another study, the presence of phosphate transporter gene, phoRP in the genome of B. cereus was documented [22]. The presence of phosphonate degradation and phosphate transport genes in stain T4S could enhance the rate of phosphate utilization by the host plants.

The presence of sulfur transport genes in the genome of an endophytic bacterium can facilitate the degradation of sulfur-containing xenobiotic compounds. It also contributes to the sulfur acquisition ability of bacterial strain and possibly in the modulation of sulfur levels in plants and soils. The identification of sulfate transport genes (sulP, cysAPUW, and $y \ln \mathrm{A})$ in B. megaterium strain STB has been documented to enhance plant growth and mitigate stress in plants [31].

Plants tend to survive in iron-limiting soil due to the abundance of siderophoreproducing microbes that ensure the acquisition and bioavailability of soluble iron for plants and microbial uptake [36]. Siderophore production can exert lethal effects on targeted phytopathogens due to the strong affinity of microbes to compete for iron in the soil [37]. Siderophore activity of strain T4S was profound. The genome revealed the presence of genes, such as $f e p \mathrm{~A}, f e o \mathrm{~A}, f e o \mathrm{~B}$, and $f e t \mathrm{~B}$ that code for iron transport, thus suggesting their strong linkage for siderophore production. The expression of siderophore genes, namely, pyoverdine homologous genes, $p v d, f h u, m b t \mathrm{H}, f p v \mathrm{~A}$, and acr $\mathrm{AB}$ from bacterial genera with potential plant growth promoting traits have been studied [38]. Douriet-Gámez et al. [39] have identified siderophore genes dhbABCF from Bacillus sp. strain B25. The results here corroborate the study of Nascimento, Hernandez, Glick, and Rossi [30] who reported the presence of genes (feo $\mathrm{AB}$ ) involved in iron transport in Pantoea phytobeneficialis strain MSR2. Furthermore, reports on several putative siderophore genes (rha $\mathrm{ABCDEF)} \mathrm{that} \mathrm{somewhat} \mathrm{mediate} \mathrm{the} \mathrm{synthesis} \mathrm{of} \mathrm{rhizobactin} \mathrm{for} \mathrm{the} \mathrm{production}$ of hydroxamate-like siderophore of B. megaterium STB1 and Sinohizobium meliloti 1021 are known [31]. Interestingly, active participation of B. megaterium STB1 in the siderophore transport pathway due to the presence of siderophore genes, yfiZ, yfh A, yfiY, and $y u s \mathrm{~V}$ that regulate iron transport in B. subtilis have suggested their influence in competitive interactions with potential pathogens and enhancement of plant growth [40]. In this study, various genes involved in biofilm formation, chemotaxis, and flagellation were detected in the genome of an endophytic bacterium strain T4S. The presence of lipopolysaccharide (LPS) genes can enhance bacterial functions to firmly stabilize their outer membrane from desiccation. Interestingly, strain T4S harbors gene glmU encoding glucosamine-1-phosphate $\mathrm{N}$-acetyltransferase involved in LPS, lipid A biosynthesis pathways. The presence of flagellar motor protein genes (motAB) was in line with Nascimento, Hernández, Glick, and Rossi [31], who have earlier reported the same genes in the genome of B. megaterium STB1. The authors further documented several other genes that were involved in the synthesis of exopolysaccharides that enhances biofilm formation and adherence of bacteria to the plant root. Similarly, teichoic acid genes responsible for the biofilm formation and root attachment were documented [31].

One of the key attributes of endophytic bacteria is the ability to produce exopolysaccharides (EPS). The expression of EPS genes in the bacterial genome has contributed to plant resistance under drought conditions and the formation of biofilm that aids surface colonization [41]. EPS functions in biofilm production confer defensive mechanisms in response to ROS and plant protection against pathogens. The biofilm formation/production by endophytic microbes could enable plants to resist environmental stressors and firm colonization within the endosphere, thus suggesting their functions in plant-microbe interactions [30]. Furthermore, EPS synthesis enhanced bacterial affinity within the host plants for various biological functions [25]. Various genes such as flgBDFGK, flhABE, 
fliCEHFKLMNPQRSY, and motAB are found in the genome of strain T4S involved in the flagellar biosynthesis pathway. Protein coding gene crp that is primarily involved in biofilm production was also identified in strain T4S. The identification of specific genes involving in biofilm production from the genome of endophytic bacterial strain associated with the root endosphere is known $[25,29]$. Based on a previous study by $\mathrm{Xu}$ et al. [42], it can be inferred that $B$. cereus T4S might have potential as a biocontrol agent due to the presence of certain gene families which have been demonstrated to be responsible for the biocontrol efficacy in experiments performed in other host/microbe systems.

Carbon sources provide the required energy for bacterial metabolism. Endophytic bacterial strain T4S contains genes involved in carbohydrate metabolism and transport through dynamic pathways, which include, pentose phosphate pathway, EMP (EmbdenMeyerhof-Parnas) glycolysis pathway, maltose, cellobiose, glucose, and ribose transport pathways, hexose metabolism pathway, GDP-mannose, N-acetyl-D-galactosamine and D-galactosamine, trehalose, myo-inositol, D-gluconate, L-lactate, L-lyxose, beta-glucosides, 2,3-diketo-L-gulonate-and-ascorbate, chitin, D-tagatose, and fructose degradation pathways, sugar transport, sugar acids transport, and trehalose-specific EIIBC component. The ability of bacterial endophytes to utilize complex carbohydrate compounds has significantly contributed to the establishment of plant-microbe interactions. Reports have shown that the amount of metabolizable sugar released from plant roots could mediate the colonization tendencies of bacterial in the root endosphere compartments and then contribute to crop yield $[43,44]$. Thus, the genomic sequencing of B. cereus T4S reveals the presence of gene families with previously reported beneficial roles in other crop-microbe associations [45], which suggests that B. cereus T4S may be a candidate in stimulating phytohormones in enhancing sunflower growth.

Owing to the genetic profiling of bacterial endophytes, they can participate in carbohydrate metabolic pathways and related carbon derivatives from the plant root exudates. The amount of carbohydrate content in plants can mediate sugar signal networking for cellular regulation and a shift in plant response to environmental stress adaptors [46]. Reports on the utilization of glucose, sucrose, maltose, and ribose as a carbon source by bacterial endophytes have been shown to have contributed to their metabolic activities [47]. Biotransformation of organic compounds for organic acids production could share a direct link for enhanced bacterial colonization with the host plants.

Production of notable genes involved in amino acid biodegradation and biotransformation could contribute to the functional attributes of bacteria in eco-niches. The presence of genes in the polyamine, amino acid opine, and 4-aminobutyrate (GABA) metabolism in strain T4S have suggested their ability to metabolize amino acid, thus contributing to microbial colonization for improved plant growth. Moreover, the presence of opines could be responsible for amino acid condensation. Opines are known as one of the chemical compounds produced by rhizobacteria that participate in plant-bacteria colonization, thus modulating root bacterial-nodulation processes. The protein-encoding myo-inositol and rhizopine metabolism (iolCDEG) involve in the degradation of these compounds suggested the importance of these compounds in bacterial colonization with plants. The role of GABA synthesis by bacterial species in synergistic interactions with plants for enhanced plant performance has been reported [30,48].

The possession of lignin degradation encoding genes, multicopper oxidase domaincontaining protein has yielded other organic compounds such as alcohols, phenolic and toxic aldehydes, several intermediates-like alcohols (gallate and protocatechuate), and aromatic compounds, vanillate [30,49]. The presence of lignin-degrading genes and other plant components could significantly facilitate endophytic colonization.

The role of root-associated bacterial endophytes such as Burkholderia, Bacillus, Pseudomonas in plant growth promotion has been reported in recent times with a promising outlook in agriculture sustainably $[25,50,51]$. Nevertheless, information regarding the phytohormone production ability of bacterial endophytes from the sunflower root endosphere as revealed by whole-genome analysis is less studied. Plant hormone synthesis is a ma- 
jor feature that distinguishes agriculturally important bacteria from one and another [52]. The detection of acdA could serve as a precursor in lowering ethylene levels in plants. Deamination of 1-aminocyclopropane-1-carboxylate (ACC) into ammonia and $\alpha$-ketobutyrate can enhance bacterial metabolism in response to sustain plant health. The detection of acdA gene in the genome of bacteria may perhaps uncover their potential in stimulating plant internal responses against environmental stressors. The positive influence of $B$. mojavensis isolated from pea (Pisum sativum) on plant growth due to possession of acdS gene has been documented [53]. IAA biosynthesis in a culture medium depends on the utilization of precursory factor (tryptophan) by the endophytic bacteria. Various bacteria isolated from the root endosphere promote plant growth and soil health and the diverse endophytic bacterial community is known to produce IAA and other plant growth-promoting traits. Genome analysis of strain T4S predicts the presence of dhaS and trpBCDES genes that are involved in L-tryptophan production, IAA production, and IPA pathway. The presence of IAA-enzyme coding genes in the genome of endophytic bacteria confirms their involvement in IAA biosynthesis. Hence, identification of plant growth-promoting genes trp ABD, trp ABCDE, and trpBE from Sphingomonas sp. LK11, Pseudomonas aeruginosa B18, and Enterobacter roggenkampii ED5 from the sugarcane root endosphere have been documented [25]. The putative candidate genes and gene families identified in B. cereus T4S have the potential for directing further experimental tests of their roles in sunflower growth similar to previous experiments examining cucumber yield in B. subtilis MBI 600 [29].

Additionally, studies on the possible novel genes that involve in IAA synthesis through the tryptophan-dependent indole-3pyruvate (IPyA) pathway by B. amyloliquefaciens SQR9a have been studied [54]. These genes are primarily involved in the conversion of IAA synthesis precursor (tryptophan) IPyA. Furthermore, pyruvate decarboxylase, pyruvate oxidase, and phenolic acid decarboxylase participate in the conversion process of IPYA to indole-3-acetaldehyde (IAAld). The observed enzyme coding gene (aldehyde dehydrogenase genes, dhaS) in strain T4S has also been implicated in the conversion process of IAAld to IAA, which further corroborates the results obtained from the genomic analysis of B. amyloliquefaciens SQR9a [54].

Some industrially and biotechnologically important enzymes from bacterial endophytes have been reported [55], and their vital role in plant defense mechanisms against phytopathogen resistance is known. Examples of these enzymes include chitinase, cellulase, glucanase, amylase, catalase, and peroxidase. In this study, various genes (lon $\mathrm{B}$, amyS, and pulA) that involved enzyme synthetic pathways were detected in strain T4S, thus suggesting the ability to stimulate plant immune response.

Various genes involved in the protection against oxidative and nitrosative stress were detected in strain T4S. The survival of plants inoculated with bacterial endophytes that thrive under high saline environments could suggest their possible use as bioinoculants to boost salt tolerance in plants [50]. The result agrees with the earlier reports on the osmotic stress tolerance genes in B. megaterium STB1 [30]. However, the authors further stressed that the presence of cold and heat shock genes ( $c s p$ and $h s p$ ), and chaperones in the genome of strain B. megaterium STB1 contributed to RNA and DNA stabilization for easy expression (translation and transcription) under cold or heat stress conditions. Although, chaperone encoding genes were not detected in strain T4S.

The participatory genes in the biological control and synthesis of volatile compounds form an essential component of the bacterial cell. The detection of ilvABCDEN gene coding for 2,3-butanediol could be linked to induction of systemic resistance in plants, and protect bacterial cells at low $\mathrm{pH}$ and other deleterious metabolites secreted from the root rhizosphere.

Commercialization of known strains of Bacillus species of the same ecotype and their activities in sustaining plant growth stand promising as a source of metabolic compounds, such as macrolactin, difficidin, and bacillaene [56]. The genomic information of strain T4S account for most similar known gene clusters specific for secondary metabolite biosynthesis that involves various biological functions in the host plants. Similar metabolic compounds 
found in the genome of $B$. velezensis have been reported to enhance plant growth and disease suppression [57]. Furthermore, it has been postulated that the genomic similarity of Bacillus species could contribute to their interaction mechanisms based on inherent genes involved in biofilm formation [58]. Information regarding the identification of antibiotic compounds in the genome of Bacillus and Streptomyces has been documented, thus suggesting their exploration as a source of biocontrol agent [59].

Interestingly, the genome of B. cereus T4S contains six important genes coding for siderophore, terpene, betalactone, and non-ribosomal peptide (NRPS), such as petrobactin, molybdenum cofactor, fengycin, and bacillibactin, bacitracin, and zwittermicin A, respectively. All these compounds contributed to the biocontrol activity of strain T4S. Siderophore, terpene, betalactone, and NRPS have been implicated in the control of phytopathogens and boosting plant response to environmental stressors [60]. Fengycin production by strain T4S stands as potent antifungal compounds that can cause cell membrane lysis and eventually cell death. Here, the result obtained in this study corroborates the findings of Teixeira et al. [58] who reported NRPS (bacillibactin) from the genome of B. velezensis CMRP 4490 . Half of the similar known clusters in strain T4S had no similar identity in the database. Hence, the unidentified or yet-to-be described products have created opportunities for future research. Different gene clusters encoding for siderophore, NRPS, and polyketide, also with other novel gene clusters were found in strain T4S. The presence of these metabolite compounds in strain T4S can serve as a source of biocontrol agents for plant protection. However, several findings on the antimicrobial compounds from $B$. velezensis against pathogenic fungi have been documented [58], but less is known on endophytic bacterium B. cereus T4S.

In our view, the aforementioned genes involved in various metabolic pathways is the first report on the genome sequencing of sunflower-associated endophytic strain T4S with novel plant growth-promoting attributes and biocontrol potential, which suggest their commercialization prospect in South Africa. A series of several genes identified may play an important role in root colonization to enhance plant growth and immunity. To confirm the implication of gene products from strain T4S on plant growth promotion, further research by chemical analytical methods is required. Hence, optimization of strain T4S based on their gene expression for use under greenhouse experiments may contribute to agricultural productivity. The effect of pure culture of strain T4S upon inoculation revealed better yield in inoculated sunflower plants than un-inoculated. This might be due to the viability and adherence of the bacterial to the surface of the seeds. It is important to state here that the sunflower seed bacterized with strain T4S germinated faster compared to the non-inoculated (Figure 4). Bacterization of sunflower seeds with strain T4S led to faster and higher growth under greenhouse experiments. Enhanced below and aboveground sunflower parameters can be explained by the suggestion that strain T4S which colonized roots interdependently enhanced root development in the uptake of nutrients from the soil for plant nutrition. In addition, the enhanced sunflower yield in terms of nutrient acquisition from soil could be a consequence of strain $\mathrm{T} 4 \mathrm{~S}$ adherence to the seeds before planting. Our findings are in agreement with the reports of Soni et al. [35] and Prashanth and Mathivanan [61] on cumin and groundnut seeds bacterized with Paenibacillus polymyxa HK4 and B. licheniformis MML2501, which showed a higher germination rate of bacterized seedlings in comparison to control. Moreover, soil physicochemical parameters and the ability of bacterial endophytes to secrete phytohormones serve as factors contributing to plant development. The CMC used as a binder help to retain water level on the seed surface as well as the source of nutrients, and their extensive use in food and pharmaceutical industries is known [62]. A significant increase in growth parameters of some inoculated plants with Bacillus spp. has been reported [63]. Thus, the results obtained from this study corroborate with the findings of Singh et al. [64] who earlier documented on the increase in shoot and root length of sunflower inoculated with Rhizobium SF48. Furthermore, improvement in the yield of sunflower treated with plant growth-promoting bacteria, as reported by different researchers, can ensure sustainable sunflower production $[1,65]$. 
The increase in the yield of sunflower inoculated with strain T4S can be linked to their genetic composition, functionally in the synthesis of phytohormones which modulate bacteria activities in enhancing sunflower yield. Furthermore, a report by Zahra et al. [66] revealed the effect of sunflower seed inoculation by endophytic actinobacteria and higher sunflower yield (plant length, weight, and flower diameter) than that of non-inoculated sunflower under greenhouse and field experiments. The authors recommended possible exploration of these bacteria in producing biofertilizers for enhanced sunflower growth, which is the focus of this study.

\section{Materials and Methods}

4.1. Isolation of Sunflower Root Endosphere Associated Endophytic Bacterium, B. cereus T4S

Sunflower roots were sourced from farmlands in Lichtenburg, South Africa $\left(26^{\circ} 4^{\prime} 31.266^{\prime \prime} \mathrm{S}\right.$, $25^{\circ} 58^{\prime} 44.442^{\prime \prime} \mathrm{E}$ ) in February 2020. Bacteria isolate was isolated from the sunflower root endosphere on Luria Bertani (LB) agar medium following the method described by Annapurna et al. [45]. Briefly, the plant roots obtained were placed in zip-lock bags on an ice-box for transportation to the laboratory within $4 \mathrm{~h}$ of collection for further analysis. For bacterial isolation, the roots were cut into small sizes and surface-sterilized using disinfectants. From the serial dilution process, $0.1 \mathrm{~mL}$ from $10^{6}$ dilutions were aseptically dispensed into sterile Petri dishes and pour plated with sterilized LB medium. Then incubated at $28^{\circ} \mathrm{C}$ for $24 \mathrm{~h}$ and then checked for colony growth. The pure isolate was obtained by streaking on fresh LB agar plates. For cultural and morphological characterization, various biochemical tests were performed. The isolate was kept on agar slants at $4{ }^{\circ} \mathrm{C}$ for further analysis. Furthermore, the isolate was preserved in $30 \%(v / v)$ glycerol at $-20^{\circ} \mathrm{C}$.

\subsection{Morphological and Biochemical Characterization of Bacterial Isolate}

The cultural attributes of the bacteria isolate were evaluated on LB media after incubation at $28^{\circ} \mathrm{C}$ for $24 \mathrm{~h}$. The cultural morphology of bacterial isolate was visualized under a light microscope (ECLIPSE E200; Nikon, Japan). Biochemical tests, such as sugar fermentation tests (mannitol, glucose, sucrose, maltose, fructose, galactose, and raffinose), catalase test, oxidase test, citrate test, nitrate utilization test, starch, and casein hydrolysis were performed.

\subsection{DNA Extraction, Polymerase Chain Reaction, and Molecular Identification of the Bacterial Isolate}

The genomic content of the pure bacterial isolate was extracted using a commercial Quick-DNA ${ }^{\mathrm{TM}}$ Miniprep Kit specific for fungi or bacteria (Zymo Research, Irvine, CA, USA; Cat. No. D6005), following the manufacturer's guide. The concentration of the extracted DNA $(\mathrm{ng} / \mu \mathrm{L})$ was measured using a NanoDrop Lite spectrophotometer (ThermoFisher Scientific, Carlsbad, CA, USA) and stored at $-80^{\circ} \mathrm{C}$. The determination of $16 \mathrm{~S}$ rDNA nucleotide sequences of the identified bacterial isolate was achieved using the amplified PCR products. The amplification process was initiated using universal oligonucleotide primers, 27F (5'-AGAGTTTGATCCTGGCTCAG- $\left.3^{\prime}\right)$ and 1492R (5'TACGGTTACCTTGTTACGACTT- $\left.3^{\prime}\right)$. A total of $25 \mu \mathrm{L}$ reaction volume for each bacterial isolate composed of $12.5 \mu \mathrm{L}$ OneTaq $2 \times$ MasterMix with the Standard Buffer, $1 \mu \mathrm{L}$ for each primer, $2 \mu \mathrm{L}$ genomic DNA, and $9.5 \mu \mathrm{L}$ nuclease-free water were used for PCR amplification on DNA Engine DYAD ${ }^{\mathrm{TM}}$ Peltier Thermal Cycler (BIO-RAD, C1000 Touch ${ }^{\mathrm{TM}}$, Hercules, CA, USA) [67]. The PCR conditions were set to initial denaturation at $94{ }^{\circ} \mathrm{C}$ for 5 min and 35 cycles of amplification. Furthermore, the denaturation temperature was set at $94{ }^{\circ} \mathrm{C}$ for $30 \mathrm{~s}$, annealing at $50^{\circ} \mathrm{C}$ for $30 \mathrm{~s}$, extension at $68^{\circ} \mathrm{C}$ for $1 \mathrm{~min}$, and a final extension at $68^{\circ} \mathrm{C}$ for $10 \mathrm{~min}$.

After amplification, PCR products were checked in $2 \%$ agarose gel prepared in $1 \times \mathrm{TAE}$ buffer, and heat in microwave for $4 \mathrm{~min}$. After cooling, $10 \mu \mathrm{L}$ ethidium bromide was added for the electrophoresis. The band size of the amplicons was determined using a $1 \mathrm{~kb}$ molecular marker. After that, the gel was visualized in a Chemidoc ${ }^{\mathrm{TM}}$ imaging system (BIO-RAD 
Laboratories, Hercules, CA, USA). Finally, $20 \mu \mathrm{L}$ of the PCR product of the bacterial isolate was placed in an ice-box pack and sent for sequencing at Inqaba Biotechnical Industries (Pty) Ltd., Pretoria, South Africa. 16S rDNA sequences for the bacterial isolate were submitted to GenBank on the NCBI online server and were assigned an accession number. The strain code and accession number of the 16S rRNA gene sequence data of the identified bacterial endophytes deposited in the GenBank are T4S and MW265423, respectively.

\subsection{Whole-Genome Sequencing (WGS)}

The extracted genomic DNA of strain T4S was fragmented using an enzymatic approach (NEB Ultra II FS kit, Ipswich, MA, USA). The fragmented DNA was selected according to size range (200-700 bp) using AMPure XP beads. Subsequently, each fragment of DNA was end-repaired and ligated on Illumina-specific adapter sequences. Furthermore, the indexing of each sample and selection based on the size in the second step was performed. The quantity of samples at dilution of standard concentration to $4 \mathrm{nM}$ was determined using a fluorometric method. After that, sequencing was performed using a NextSeq mid-out kit (300 cycles) on Illumina's NextSeq platform, following a guideline as described by the manufacturer. The resulting $400 \mathrm{Mb}$ of data $(2 \times 150 \mathrm{bp}$ long paired-end reads) were obtained for each sample.

WGS analysis was performed by submitting each sequence (FASTQ file) to the predictive biology online server and data science platform, KBase (https://kbase.us/) (accessed on the 23 July 2021) [68]. First, sequences were uploaded for read processing, and read quality assessment was achieved using FastQC (version 0.11.5) [69]. The removal of sequence adaptor and low-quality bases of the paired-end Illumina raw sequence reads were performed with trimmomatic (version 0.36) [70] to obtain high-quality sequence reads. Furthermore, sequence reads were assembled with SPAdes (version 3.13.0) [71]. After assembly, contigs annotation was performed using RASTtk (Rapid Annotations using Subsystems Technology toolkit-version 1.073) online server to categorize the distribution and functions of the predicted genes into a subsystem (https: / / rast.nmpdr.org/) (accessed on the 26 June 2021). The bioinformatics analysis was performed using default settings. The prediction of functional protein-coding genes (PCG) was obtained from the genomic protein output after processing in NCBI. Metabolic pathways of biomolecules were obtained from KEGG (Kyoto Encyclopedia of Genes and Genomes) on RAST (https:/ / rast.nmpdr.org/rast.cgi/) (accessed on the 26 June 2021). The circular genome visualization was obtained from kbase (https://kbase.us/) (accessed on the 23 July 2021), while the phylogeny analysis was performed using MrBayes (http: / / www.phylogeny.fr/one_task.cgi?task_type=mrbayes) (accessed on the 23 July 2021) (version 3.2.6) [68,72]. Secondary metabolites were determined by antiSMASH (version 6.0.0) (https: / / antismash.secondarymetabolites.org) (accessed on the 26 June 2021) [73].

\subsection{Plant Growth-Promoting Screening \\ 4.5.1. Phosphate Solubilization Screening}

The qualitative screening of B. cereus T4S for the solubilization of phosphate was performed according to the modified method of Khan et al. [74]. For the quantitative assay, phosphate solubilization tendencies of the bacteria isolate were performed by inoculating $10 \mathrm{~mL}$ sterile Pikovskaya broth in $50 \mathrm{~mL}$ Falcon tubes with $0.1 \mathrm{~mL}\left(10^{6} \mathrm{CFU} / \mathrm{mL}\right)$ freshly grown bacterial culture, incubated at $30^{\circ} \mathrm{C}$ for $120 \mathrm{~h}$ at $180 \mathrm{rpm}$ on a rotary shaker machine. Bacterial supernatant was obtained after cold centrifugation $\left(4{ }^{\circ} \mathrm{C}\right)$ of $10 \mathrm{~mL}$ bacterial cultures at 10,000 rpm for $5 \mathrm{~min}$. Four milliliters $(4 \mathrm{~mL})$ of the color reagent [(1:1:1:2 ratio $3 \mathrm{M} \mathrm{H}_{2} \mathrm{SO}_{4}, 10 \%(w / v)$ ascorbic acid, $2.5 \%(w / v)$ ammonium molybdate and distilled water], were added to $10 \%(w / v)$ of $5 \mathrm{~mL}$ trichloroacetic acid inside test tubes. The tubes were allowed to stand for $15 \mathrm{~min}$ upon incubation at room temperature. The quantity of phosphate content was measured according to phosphomolybdate, a blue method at an absorbance of $820 \mathrm{~nm}$. The phosphate solubilization potential by the bacterium in the 
Pikovskaya broth was determined from the phosphate $\left(\mathrm{KH}_{2} \mathrm{PO}_{4}\right)$ standard curve. Medium without bacterial inoculation serves as the control.

\subsubsection{Siderophore Screening}

Siderophore producing ability of B. cereus T4S was performed on chrome azurol S (CAS) medium following the methods of Khan et al. [74] with little modifications. The quantity of siderophore produced was determined by inoculating LB broth solution containing CAS with $0.1 \mathrm{~mL}$ of $24-\mathrm{h}$ old bacterial culture and incubated at $180 \mathrm{rpm}$ on a rotary shaker for $164 \mathrm{~h}$. Centrifugation of bacterial culture suspension was achieved at $8000 \times g$ for $10 \mathrm{~min}$. Half a milliliter of the cell filtrate was added to $0.5 \mathrm{~mL}$ CAS reagent and properly mixed, then incubated for $120 \mathrm{~s}$ at room temperature. The quantity of siderophore released was measured at $630 \mathrm{~nm}$ using a spectrophotometer (Thermo Spectronic, Merck Chemicals, Pretoria, South Africa). The siderophore estimate was obtained from the regression equation of the standard curve.

\subsubsection{Exopolysaccharide (EPS) Test}

Bacillus cereus T4S was qualitatively screened for EPS production following the modified method of Igiehon et al. [16]. The square-sized sterile Whatman filter paper No. 1 was aseptically and gently placed onto sterile molten LB agar plates. Two microliters $(2 \mu \mathrm{L})$ of freshly grown 24-h bacterial culture were directly inoculated on the surface of the filter paper placed inside agar plates supplemented with $10 \%$ sucrose with $\mathrm{pH}$ adjusted to 7 . Subsequently, the inoculated plates were incubated at $28^{\circ} \mathrm{C}$ for 5 days. After that, the formation of mucoid colonies around the square-size filter paper depicted EPS production.

\subsubsection{Indole Acetic Acid Production}

Indole acetic acid synthesis by B. cereus T4S was conducted according to Gutierrez et al. [75]. Ten milliliters $(10 \mathrm{~mL}) \mathrm{LB}$ broth supplemented with tryptophan were aseptically inoculated with $100 \mu \mathrm{L}$ freshly grown bacterial culture $\left(10^{6} \mathrm{CFUml}^{-1}\right)$ and incubated at $28^{\circ} \mathrm{C}$ for 7 days at $120 \mathrm{rpm}$ in a rotary shaker incubator (SI-600, LAB Companion, Seoul, Korea). Following incubation, the bacterial suspension was cold centrifuged $\left(4^{\circ} \mathrm{C}\right)$ at 10,000 rpm for $5 \mathrm{~min}$ to obtain a cell-free supernatant layer. From the crude extract, $1 \mathrm{~mL}$ of supernatant was measured into a clean tube, and $2 \mathrm{~mL}$ Salkowski reagent (1:30:50 ratio of $0.5 \mathrm{M} \mathrm{FeCl}_{3}$ solution: $95 \% w / w$ sulfuric acid: distilled water) was added. Then, a drop of $10 \mathrm{mM}$ orthophosphoric acid was also added to the mixture and incubated for $10 \mathrm{~min}$ at room temperature for color development. The appearance of pink coloration in tubes after incubation in the dark indicated a positive result. An un-inoculated tube serves as the control. From the reacting mixture and control tube after incubation, the absorbance was determined at $530 \mathrm{~nm}$ using UV-spectrophotometer (ThermoFisher Scientific, Carlsbad, CA, USA). IAA concentration was evaluated from the IAA gradient standard curve (SC).

\subsection{Inoculum Preparation and Seed Treatment for the Greenhouse Experiment}

4.6.1. Inoculum Preparation and Seed Treatment

A seed inoculation assay was used to facilitate bacterial adherence to the disinfected sunflower seeds. The effectiveness of sunflower seed inoculation was performed following the methods of Ullah et al. [76]. The bacterial inoculum size in LB broth at 24-h incubation was standardized to $0.5\left(10^{6} \mathrm{CFU} / \mathrm{mL}\right)$ at $\mathrm{OD}_{600}$. Surface sterilization of the seeds was performed by washing in sterile distilled water to remove floating-unhealthy seeds and dirt, and disinfected in 70\% ethanol for $3 \mathrm{~min}$, followed by 3\% hypochlorite for $1 \mathrm{~min}$, then immersed in $70 \%$ alcohol for 2 min with final washing with sterile distilled water. Prepared LB broth inoculated with fresh bacterial culture was incubated on shaker incubator machine at $180 \mathrm{rpm}$ for $24 \mathrm{~h}$. The bacterial cells in the broth culture were harvested by cold centrifugation $\left(4^{\circ} \mathrm{C}\right)$ at $8000 \times g$ for $10 \mathrm{~min}$ to obtain the pelletized cells and then washed in $0.85 \%$ normal saline solution. The centrifugation and washing of the pellets were performed under sterile conditions. The sterilized seeds were suspended in a bacterial liquid medium 
(suspension) containing $1 \%(v / w)$ carboxymethyl cellulose (CMC) in a $250 \mathrm{~mL}$ flask and agitated for $60 \mathrm{~min}$. The CMC serves as a sticker that causes the adhesion of bacterial mass to the seeds. The seeds suspended in sterile distilled water without bacterial inoculum serve as control.

\subsubsection{Greenhouse Experimental Study}

The soil used for the experiment was sourced from agricultural farmlands in NorthWest University, Mafikeng Campus. Soil debris and other plant materials were removed, air dry, and sieved with a $2 \mathrm{~mm}$ micro stainless steel mesh sieve, and the soil was placed inside autoclavable plastic bags and sterilized at $121^{\circ} \mathrm{C}$ for $15 \mathrm{~min}$. This step was repeated three times to ensure all spore formers, vegetative cells, and forms of life were eliminated. The level of soil sterility after autoclaving was tested by plating on LB agar. Sterilized soil was allowed to cool for 2 days after which $10 \mathrm{~kg}$ of soil was aseptically transferred into plastic pots.

The inoculated and non-inoculated pots were arranged randomly in a complete randomized design (CRD) with 8 replicates for each treatment at a $10 \mathrm{~cm}$ distance apart in a greenhouse under natural light. The plastic pots measured $34 \mathrm{~cm}$ in diameter and $29 \mathrm{~cm}$ tall were washed with sterile water and sterilized with 15\% sodium hypochlorite solution before filling with $15 \mathrm{~kg}$ dry-sterilized loamy soil. The pots containing the sterile soil were moistened with $500 \mathrm{~mL}$ sterilized water before sowing. Ten seeds were sown per pot at a depth of $1.5 \mathrm{~cm}$. After seed emergence, i.e., at 8 days, thinning was performed, leaving one sunflower seedling in a pot. Growing sunflower seedlings were maintained on a day-night cycle of 13-14 h natural light, a temperature of $30 \pm 2{ }^{\circ} \mathrm{C}$, and relative humidity of $85 \%$. The pots were moistened with an equal amount of water and maintained daily. Pots containing seedlings without inoculation serve as control. The plants were harvested at maturity after 132 days of planting.

\subsubsection{Sunflower Morphological Parameters Below-and-Above-Ground Level}

The data collected based on sunflower morphological parameters after harvesting included the number of lateral roots, root number, fresh weight, root weight (dry), shoot weight (dry), taproot length, etc. These parameters were considered following the method described by Igiehon et al. [16]. After harvesting from a greenhouse, sunflower plants were taken to the laboratory. The soil adhering to plant roots was thoroughly washed under running sterile water. The fresh weight of roots and shoots was measured using a weighing balance (Wagi Elektroniczne, Radom, Poland). Furthermore, plant roots and shoots were oven-dry at $60{ }^{\circ} \mathrm{C}$ for $24 \mathrm{~h}$ and re-weighed on a weighing balance for the determination of roots and shoot dry weights.

\subsubsection{Determination of Sunflower Yield Parameters}

The sunflower yield parameters were obtained above plant level. The parameters considered include seed weight (fresh and dry), total seed weight (dry), head weight (fresh and dry). After drying, sunflower seeds were manually separated from the sunflower head containing seeds. Seeds were dried in an oven at $60^{\circ} \mathrm{C}$ for $24 \mathrm{~h}$, and dry weight was measured on a weighing balance. The plant samples were kept in plastic bags for further analysis. The whole experiment was repeated in triplicate for each treatment.

\subsubsection{Soil Variable Analysis}

Approximately $0.5 \mathrm{~kg}$ of sieved soil was used for soil physical and chemical parameters determination [16]. The chemical parameters such as a percentage (\%) silt, clay, and sand, and chemical parameters such as magnesium, iron, potassium, phosphorus, manganese, organic carbon, organic matter, $\mathrm{pH}$, and total nitrogen were evaluated. 


\subsection{Statistical Analysis}

The analysis of data from this study was analyzed using SPSS version 16.0. One-way analysis of variance (ANOVA) was performed for the data, followed by Duncan test at $5 \%$ level of significance to determine differences between mean. For each treatment, generated data were presented as arithmetic means \pm standard deviation.

\section{Conclusions}

From this study, it is evident that $B$. cereus $\mathrm{T} 4 \mathrm{~S}$ could be projected into agricultural and crop management based on the possession of putative genes annotated to different biological pathways. The presence of these genes can be overviewed from biotechnological perspectives into main functions such as synthesis of growth hormones, volatile organic compounds, and biocontrol agents, metabolism of organic substrates, and solubilization of essential nutrients. Primarily, the abundance of secondary metabolite gene clusters could provide more insights in the search for a new source of antibiotics. Interestingly, the results from this study have provided new information regarding the genomic competence of $B$. cereus T4S associated with sunflower. Furthermore, the previously demonstrated ability of other B. cereus strains with strong affinity in the establishment of plant-bacterial interactions based on notable genes involved in motility, biofilm production, chemotaxis, and attachment to plant root surfaces could make B. cereus T4S a suitable candidate in the synthesis of bioinoculants with promising biotechnological application in agriculture for improved sunflower yield.

Supplementary Materials: The following are available online at https:/ /www.mdpi.com/article/ 10.3390/plants10091776/s1, Table S1: Biochemical, cultural characterization of B. cereus T4S: Table S2: Protein secretion systems genes; Table S3: Genes involved in sulfur metabolism; Table S4: Genes involved in motility, biofilm formation, and chemotaxis; Table S5: Genes involved in attachment to plant surfaces; Table S6: Genes involved in the protection against oxidative and nitrosative stress; Table S7: Genes involved in carbohydrate metabolism; Table S8: Genes involved in carbohydrate transport; Table S9: Genes involved in the metabolism of organic acids; Table S10: Genes involved in amino acid metabolism and transport; Table S11: Genes involved in opine and GABA transport and metabolism; Table S12: Genes involved in lignin degradation and degradation against toxic peroxides; Table S13: Genes involved in biological control; Table S14: Physical and chemical analysis of the soil samples.

Author Contributions: B.S.A. managed the literature searches, carried out the laboratory work, interpreted the results, and wrote the manuscript's first draft. A.S.A. assisted in genome analysis, reviewed the drafts, and proofread the manuscript while O.O.B., the principal investigator, provided academic input, thoroughly critiqued the manuscript, proofread the draft, and secured funds for the research. All authors have read and agreed to the published version of the manuscript.

Funding: This study was funded by the National Research Foundation of South Africa (Grant numbers: $123634 ; 132595)$.

Informed Consent Statement: Not applicable.

Data Availability Statement: From the NCBI database output, the Bioproject number is https: //www.ncbi.nlm.nih.gov/bioproject/PRJNA706601, and Sequence Read Archive (SRA) number is https:/ / www.ncbi.nlm.nih.gov/sequencereadarchive/SRR13887969, and BioSample number is https://www.ncbi.nlm.nih.gov/biosample/SAMN18138757. The genome accession number JAFNAY000000000 was assigned to the strain T4S.

Acknowledgments: B.S.A. wants to thank the National Research Foundation of South Africa and The World Academy of Science (TWAS) for NRF-TWAS African Renaissance Doctoral scholarship (Grant UID: 116100). A.S.A. is grateful to North-West University for a postdoctoral fellowship award. O.O.B. acknowledges National Research Foundation of South Africa for the grants (Grant numbers: 123634; 132595), supporting research in her laboratory.

Conflicts of Interest: The authors declare no conflict of interest. 


\section{References}

1. Majeed, A.; Abbasi, M.K.; Hameed, S.; Imran, A.; Naqqash, T.; Hanif, M.K. Isolation and characterization of sunflower associated bacterial strain with broad spectrum plant growth promoting traits. Int. J. Biosci. 2018, 13, 110-123.

2. Adeleke, B.S.; Babalola, O.O. Biotechnological overview of agriculturally important endophytic fungi. Hortic. Environ. Biotechnol. 2021, 62, 507-520. [CrossRef]

3. Huang, C.-J.; Zheng, P.-X.; Ou, J.-Y.; Lin, Y.-C.; Chen, C.-Y. Complete genome sequence of Bacillus cereus C1L, a plant growthpromoting rhizobacterium from the rhizosphere of Formosa lily in Taiwan. Genome Announc. 2017, 5, e01290-17. [CrossRef] [PubMed]

4. Adeleke, B.S.; Babalola, O.O. Oilseed crop sunflower (Helianthus annuus) as a source of food: Nutritional and health benefits. Food Sci. Nutr. 2020, 8, 4666-4684. [CrossRef] [PubMed]

5. Sharma, N.; Singhvi, R. Effects of chemical fertilizers and pesticides on human health and environment: A review. Int. J. Agric. Environ. Biotechnol. 2017, 10, 675-680. [CrossRef]

6. Sun, R.; Guo, X.; Wang, D.; Chu, H. Effects of long-term application of chemical and organic fertilizers on the abundance of microbial communities involved in the nitrogen cycle. Appl. Soil Ecol. 2015, 95, 171-178. [CrossRef]

7. Emami, S.; Alikhani, H.A.; Pourbabaei, A.A.; Etesami, H.; Sarmadian, F.; Motessharezadeh, B. Assessment of the potential of indole-3-acetic acid producing bacteria to manage chemical fertilizers application. Int. J. Environ. Res. 2019, 13, 603-611. [CrossRef]

8. Olanrewaju, O.S.; Glick, B.R.; Babalola, O.O. Mechanisms of action of plant growth promoting bacteria. World J. Microbiol. Biotechnol. 2017, 33, 197. [CrossRef]

9. Akinola, S.A.; Babalola, O.O. The importance of adverse soil microbiomes in the light of omics: Implications for food safety. Plant Soil Environ. 2020, 66, 421-430. [CrossRef]

10. Rho, H.; Hsieh, M.; Kandel, S.L.; Cantillo, J.; Doty, S.L.; Kim, S.-H. Do endophytes promote growth of host plants under stress? A meta-analysis on plant stress mitigation by endophytes. Microb. Ecol. 2018, 75, 407-418. [CrossRef]

11. Khamwan, S.; Boonlue, S.; Riddech, N.; Jogloy, S.; Mongkolthanaruk, W. Characterization of endophytic bacteria and their response to plant growth promotion in Helianthus tuberosus L. Biocatal. Agric. Biotechnol. 2018, 13, 153-159. [CrossRef]

12. Adeleke, B.S.; Babalola, O.O. The endosphere microbial communities, a great promise in agriculture. Int. Microbiol. 2020, $24,1-17$. [CrossRef]

13. Santoyo, G.; Moreno-Hagelsieb, G.; del Carmen Orozco-Mosqueda, M.; Glick, B.R. Plant growth-promoting bacterial endophytes. Microbiol. Res. 2016, 183, 92-99. [CrossRef]

14. Ding, H.; Niu, B.; Fan, H.; Li, Y.; Wang, Q. Draft genome sequence of Bacillus cereus 905, a plant growth-promoting rhizobacterium of wheat. Genome Announc. 2016, 4, e00489-16. [CrossRef]

15. Ghorchiani, M.; Etesami, H.; Alikhani, H.A. Improvement of growth and yield of maize under water stress by co-inoculating an arbuscular mycorrhizal fungus and a plant growth promoting rhizobacterium together with phosphate fertilizers. Agric. Ecosyst. Environ. 2018, 258, 59-70. [CrossRef]

16. Igiehon, N.O.; Babalola, O.O.; Aremu, B.R. Genomic insights into plant growth promoting rhizobia capable of enhancing soybean germination under drought stress. BMC Microbiol. 2019, 19, 159. [CrossRef]

17. Subramanian, P.; Kim, K.; Krishnamoorthy, R.; Sundaram, S.; Sa, T. Endophytic bacteria improve nodule function and plant nitrogen in soybean on co-inoculation with Bradyrhizobium japonicum MN110. Plant Growth Reg. 2015, 76, 327-332. [CrossRef]

18. Ríos-Ruiz, W.F.; Torres-Chávez, E.E.; Torres-Delgado, J.; Rojas-García, J.C.; Bedmar, E.J.; Valdez-Nuñez, R.A. Inoculation of bacterial consortium increases rice yield (Oryza sativa L.) reducing applications of nitrogen fertilizer in San Martin region, Peru. Rhizosphere 2020, 14, 100200. [CrossRef]

19. Hashem, A.; Tabassum, B.; Fathi Abd_Allah, E. Bacillus subtilis: A plant-growth promoting rhizobacterium that also impacts biotic stress. Saudi J. Biol. Sci. 2019, 26, 1291-1297. [CrossRef]

20. Salwan, R.; Sharma, V. Genome wide underpinning of antagonistic and plant beneficial attributes of Bacillus sp. SBA12. Genomics 2020, 112, 2894-2902. [CrossRef]

21. Egidi, E.; Wood, J.L.; Mathews, E.; Fox, E.; Liu, W.; Franks, A.E. Draft genome sequence of Bacillus cereus LCR12, a plant growth-promoting rhizobacterium isolated from a heavy metal-contaminated environment. Genome Announc. 2016, 4, e01041-16. [CrossRef] [PubMed]

22. Zeng, Q.; Xie, J.; Li, Y.; Gao, T.; Xu, C.; Wang, Q. Comparative genomic and functional analyses of four sequenced Bacillus cereus genomes reveal conservation of genes relevant to plant-growth-promoting traits. Sci. Rep. 2018, 8, 17009. [CrossRef] [PubMed]

23. Hong, C.E.; Kim, J.U.; Lee, J.W.; Bang, K.H.; Jo, I.-H. Complete genome sequence of the endophytic bacterium Bacillus cereus PgBE311, isolated from Panax ginseng. Microbiol. Res. Announc. 2018, 7, e01382-18. [CrossRef] [PubMed]

24. Bamisile, B.S.; Dash, C.K.; Akutse, K.S.; Keppanan, R.; Afolabi, O.G.; Hussain, M.; Qasim, M.; Wang, L. Prospects of endophytic fungal entomopathogens as biocontrol and plant growth promoting agents: An insight on how artificial inoculation methods affect endophytic colonization of host plants. Microbiol. Res. 2018, 217, 34-50. [CrossRef] [PubMed]

25. Singh, P.; Singh, R.K.; Guo, D.-J.; Sharma, A.; Singh, R.N.; Li, D.-P.; Malviya, M.K.; Song, X.-P.; Lakshmanan, P.; Yang, L.-T. Whole genome analysis of sugarcane root-associated endophyte Pseudomonas aeruginosa B18-A plant growth-promoting bacterium with antagonistic potential against Sporisorium scitamineum. Front. Microbiol. 2021, 12, 104. [CrossRef] [PubMed] 
26. Kumar, V.; Jain, L.; Jain, S.K.; Chaturvedi, S.; Kaushal, P. Bacterial endophytes of rice (Oryza sativa L.) and their potential for plant growth promotion and antagonistic activities. S. Afr. J. Bot. 2020, 134, 50-63. [CrossRef]

27. Passari, A.K.; Chandra, P.; Mishra, V.K.; Leo, V.V.; Gupta, V.K.; Kumar, B.; Singh, B.P. Detection of biosynthetic gene and phytohormone production by endophytic actinobacteria associated with Solanum lycopersicum and their plant-growth-promoting effect. Res. Microbiol. 2016, 167, 692-705. [CrossRef]

28. Ellouze, W.; Hamel, C.; Bouzid, S.; St-Arnaud, M. Root endophytes modify the negative effects of chickpea on the emergence of durum wheat. Appl. Soil Ecol. 2015, 96, 201-210. [CrossRef]

29. Samaras, A.; Nikolaidis, M.; Antequera-Gómez, M.L.; Cámara-Almirón, J.; Romero, D.; Moschakis, T.; Amoutzias, G.D.; Karaoglanidis, G.S. Whole genome sequencing and root colonization studies reveal novel insights in the biocontrol potential and growth promotion by Bacillus subtilis MBI 600 on cucumber. Front. Microbiol. 2020, 11, 600393. [CrossRef]

30. Nascimento, F.X.; Hernandez, A.G.; Glick, B.R.; Rossi, M.J. The extreme plant-growth-promoting properties of Pantoea phytobeneficialis MSR2 revealed by functional and genomic analysis. Environ. Microbiol. 2020, 22, 1341-1355. [CrossRef]

31. Nascimento, F.X.; Hernández, A.G.; Glick, B.R.; Rossi, M.J. Plant growth-promoting activities and genomic analysis of the stressresistant Bacillus megaterium STB1, a bacterium of agricultural and biotechnological interest. Biotechnol. Rep. 2020, 25, e00406. [CrossRef]

32. Singh, R.K.; Kumar, D.P.; Singh, P.; Solanki, M.K.; Srivastava, S.; Kashyap, P.L.; Kumar, S.; Srivastava, A.K.; Singhal, P.K.; Arora, D.K. Multifarious plant growth promoting characteristics of chickpea rhizosphere associated Bacilli help to suppress soil-borne pathogens. Plant Growth Reg. 2014, 73, 91-101. [CrossRef]

33. Mehta, P.; Walia, A.; Kakkar, N.; Shirkot, C. Tricalcium phosphate solubilisation by new endophyte Bacillus methylotrophicus CKAM isolated from apple root endosphere and its plant growth-promoting activities. Acta Physiol. Plant. 2014, 36, 2033-2045. [CrossRef]

34. Ribeiro, V.P.; Marriel, I.E.; Sousa, S.M.d.; Lana, U.G.d.P.; Mattos, B.B.; Oliveira, C.A.d.; Gomes, E.A. Endophytic Bacillus strains enhance pearl millet growth and nutrient uptake under low-P. Braz. J. Microbiol. 2018, 49, 40-46. [CrossRef]

35. Soni, R.; Rawal, K.; Keharia, H. Genomics assisted functional characterization of Paenibacillus polymyxa HK4 as a biocontrol and plant growth promoting bacterium. Microbiol. Res. 2021, 248, 126734. [CrossRef]

36. Hardoim, P.R.; Van Overbeek, L.S.; Berg, G.; Pirttilä, A.M.; Compant, S.; Campisano, A.; Döring, M.; Sessitsch, A. The hidden world within plants: Ecological and evolutionary considerations for defining functioning of microbial endophytes. Microbiol. Mol. Biol. Rev. 2015, 79, 293-320. [CrossRef]

37. Zhang, L.; Zhang, W.; Li, Q.; Cui, R.; Wang, Z.; Wang, Y.; Zhang, Y.-Z.; Ding, W.; Shen, X. Deciphering the root endosphere microbiome of the desert plant Alhagi sparsifolia for drought resistance-promoting bacteria. Appl. Environ. Microbiol. 2020, 86, 02863-19. [CrossRef]

38. Gupta, A.; Gopal, M.; Thomas, G.V.; Manikandan, V.; Gajewski, J.; Thomas, G.; Seshagiri, S.; Schuster, S.C.; Rajesh, P.; Gupta, R. Whole genome sequencing and analysis of plant growth promoting bacteria isolated from the rhizosphere of plantation crops coconut, cocoa and arecanut. PLoS ONE 2014, 9, e104259. [CrossRef]

39. Douriet-Gámez, N.R.; Maldonado-Mendoza, I.E.; Ibarra-Laclette, E.; Blom, J.; Calderón-Vázquez, C.L. Genomic analysis of Bacillus sp. strain B25, a biocontrol agent of maize pathogen Fusarium verticillioides. Curr. Microbiol. 2018, 75, 247-255. [CrossRef]

40. Ollinger, J.; Song, K.-B.; Antelmann, H.; Hecker, M.; Helmann, J.D. Role of the Fur regulon in iron transport in Bacillus subtilis. J. Bacterio. 2006, 188, 3664-3673. [CrossRef]

41. Janczarek, M.; Rachwał, K.; Cieśla, J.; Ginalska, G.; Bieganowski, A. Production of exopolysaccharide by Rhizobium leguminosarum bv. trifolii and its role in bacterial attachment and surface properties. Plant Soil 2015, 388, 211-227. [CrossRef]

42. Xu, Y.-B.; Chen, M.; Zhang, Y.; Wang, M.; Wang, Y.; Huang, Q.-b.; Wang, X.; Wang, G. The phosphotransferase system gene ptsI in the endophytic bacterium Bacillus cereus is required for biofilm formation, colonization, and biocontrol against wheat sharp eyespot. FEMS Microbiol. Lett. 2014, 354, 142-152. [CrossRef] [PubMed]

43. Jha, Y.; Subramanian, R. Effect of root-associated bacteria on soluble sugar metabolism in plant under environmental stress. In Plant Metabolites and Regulation under Environmental Stress; Elsevier: Amsterdam, The Netherlands, 2018; Volume 12, pp. 231-240.

44. Paul, D.; Lade, H. Plant-growth-promoting rhizobacteria to improve crop growth in saline soils: A review. Agron. Sustain. Develop. 2014, 34, 737-752. [CrossRef]

45. Annapurna, K.; Govindasamy, V.; Sharma, M.; Ghosh, A.; Chikara, S.K. Whole genome shotgun sequence of Bacillus paralicheniformis strain KMS 80, a rhizobacterial endophyte isolated from rice (Oryza sativa L.). 3 Biotech 2018, 8, 223. [CrossRef]

46. Fouda, A.; Eid, A.M.; Elsaied, A.; El-Belely, E.F.; Barghoth, M.G.; Azab, E.; Gobouri, A.A.; Hassan, S.E.-D. Plant growth-promoting endophytic bacterial community inhabiting the leaves of Pulicaria incisa (Lam.) DC Inherent to arid regions. Plants 2021, 10, 76. [CrossRef]

47. Joshi, E.; Iyer, B.; Rajkumar, S. Glucose and arabinose dependent mineral phosphate solubilization and its succinate-mediated catabolite repression in Rhizobium sp. RM and RS. J. Biosci. Bioengin. 2019, 128, 551-557. [CrossRef]

48. Bown, A.W.; Shelp, B.J. Plant GABA: Not just a metabolite. Trends Plant Sci. 2016, 21, 811-813. [CrossRef]

49. Shi, X.; Liu, Q.; Ma, J.; Liao, H.; Xiong, X.; Zhang, K.; Wang, T.; Liu, X.; Xu, T.; Yuan, S. An acid-stable bacterial laccase identified from the endophyte Pantoea ananatis Sd-1 genome exhibiting lignin degradation and dye decolorization abilities. Biotechnol. Lett. 2015, 37, 2279-2288. [CrossRef] 
50. Dubey, A.; Saiyam, D.; Kumar, A.; Hashem, A.; Abd_Allah, E.F.; Khan, M.L. Bacterial root endophytes: Characterization of their competence and plant growth promotion in soybean (Glycine max (L.) Merr.) under drought stress. Int. J. Environ. Res. Pub. Health 2021, 18, 931. [CrossRef]

51. Khalil, A.M.A.; Hassan, S.E.-D.; Alsharif, S.M.; Eid, A.M.; Ewais, E.E.-D.; Azab, E.; Gobouri, A.A.; Elkelish, A.; Fouda, A. Isolation and characterization of fungal endophytes isolated from medicinal plant Ephedra pachyclada as plant growth-promoting. Biomolecules 2021, 11, 140. [CrossRef]

52. Daud, N.S.; Mohd Din, A.R.J.; Rosli, M.A.; Azam, Z.M.; Othman, N.Z.; Sarmidi, M.R. Paenibacillus polymyxa bioactive compounds for agricultural and biotechnological applications. Biocatal. Agric. Biotechnol. 2019, 18, 101092. [CrossRef]

53. Maheshwari, R.; Bhutani, N.; Suneja, P. Isolation and characterization of ACC deaminase producing endophytic Bacillus mojavensis PRN2 from Pisum sativum. Iran. J. Biotechnol. 2020, 18, 11-20.

54. Shao, J.; Li, S.; Zhang, N.; Cui, X.; Zhou, X.; Zhang, G.; Shen, Q.; Zhang, R. Analysis and cloning of the synthetic pathway of the phytohormone indole-3-acetic acid in the plant-beneficial Bacillus amyloliquefaciens SQR9. Microb. Cell Factories 2015, 14, 130. [CrossRef]

55. Zaferanloo, B.; Virkar, A.; Mahon, P.J.; Palombo, E.A. Endophytes from an Australian native plant are a promising source of industrially useful enzymes. World J. Microbiol. Biotechnol. 2013, 29, 335-345. [CrossRef]

56. Venugopalan, A.; Srivastava, S. Endophytes as in vitro production platforms of high value plant secondary metabolites. Biotechnol. Adv. 2015, 33, 873-887. [CrossRef]

57. Sibponkrung, S.; Kondo, T.; Tanaka, K.; Tittabutr, P.; Boonkerd, N.; Teaumroong, N.; Yoshida, K.-I. Genome sequence of Bacillus velezensis S141, a new strain of plant growth-promoting rhizobacterium isolated from soybean rhizosphere. Microbiol. Res. Announc. 2017, 5, e01312-17. [CrossRef]

58. Teixeira, G.M.; Mosela, M.; Nicoletto, M.L.A.; Ribeiro, R.A.; Hungria, M.; Youssef, K.; Higashi, A.Y.; Mian, S.; Ferreira, A.S.; Gonçalves, L.S.A. Genomic insights into the antifungal activity and plant growth-promoting ability in Bacillus velezensis CMRP 4490. Front. Microbiol. 2020, 11, 618415. [CrossRef]

59. Albarano, L.; Esposito, R.; Ruocco, N.; Costantini, M. Genome mining as new challenge in natural products discovery. Mar. Drugs 2020, 18, 199. [CrossRef]

60. Boncan, D.A.T.; Tsang, S.S.; Li, C.; Lee, I.H.; Lam, H.-M.; Chan, T.-F.; Hui, J.H. Terpenes and terpenoids in plants: Interactions with environment and insects. Int. J. Mol. Sci. 2020, 21, 7382. [CrossRef]

61. Prashanth, S.; Mathivanan, N. Growth promotion of groundnut by IAA producing rhizobacteria Bacillus licheniformis MML2501. Arch. Phytopathol. Plant Prot. 2010, 43, 191-208. [CrossRef]

62. Chukwuneme, C.F.; Babalola, O.O.; Kutu, F.R.; Ojuederie, O.B. Characterization of actinomycetes isolates for plant growth promoting traits and their effects on drought tolerance in maize. J. Plant Interact. 2020, 15, 93-105. [CrossRef]

63. Mayak, S.; Tirosh, T.; Glick, B.R. Plant growth-promoting bacteria confer resistance in tomato plants to salt stress. Plant Physiol. Biochem. 2004, 42, 565-572. [CrossRef]

64. Singh, S.; Gowtham, H.; Murali, M.; Hariprasad, P.; Lakshmeesha, T.; Murthy, K.N.; Amruthesh, K.; Niranjana, S. Plant growth promoting ability of ACC deaminase producing rhizobacteria native to sunflower (Helianthus annuus L.). Biocatal. Agric. Biotechnol. 2019, 18, 101089. [CrossRef]

65. Leff, J.W.; Lynch, R.C.; Kane, N.C.; Fierer, N. Plant domestication and the assembly of bacterial and fungal communities associated with strains of the common sunflower, Helianthus annuus. New Phytol. 2017, 214, 412-423. [CrossRef] [PubMed]

66. Zahra, T.; Hamedi, J.; Mahdigholi, K. Endophytic actinobacteria of a halophytic desert plant Pteropyrum olivieri: Promising growth enhancers of sunflower. 3 Biotech 2020, 10, 1-13. [CrossRef]

67. Turner, S.; Pryer, K.M.; Miao, V.P.; Palmer, J.D. Investigating deep phylogenetic relationships among cyanobacteria and plastids by small subunit rRNA sequence analysis. J. Eukaryot. Microbiol. 1999, 46, 327-338. [CrossRef]

68. Arkin, A.P.; Cottingham, R.W.; Henry, C.S.; Harris, N.L.; Stevens, R.L.; Maslov, S.; Dehal, P.; Ware, D.; Perez, F.; Canon, S. KBase: The United States department of energy systems biology knowledgebase. Nat. Biotechnol. 2018, 36, 566-569. [CrossRef]

69. Bioinformatics, B. FastQC: A Quality Control Tool for High Throughput Sequence Data; Babraham Institute: Cambridge, UK, 2011; Available online: http:/ / www.bioinformatics.babraham.ac.uk/projects/fastqc (accessed on 23 January 2021).

70. Bolger, A.M.; Lohse, M.; Usadel, B. Trimmomatic: A flexible trimmer for Illumina sequence data. Bioinformatics 2014, 30, 2114-2120. [CrossRef]

71. Nurk, S.; Bankevich, A.; Antipov, D.; Gurevich, A.A.; Korobeynikov, A.; Lapidus, A.; Prjibelski, A.D.; Pyshkin, A.; Sirotkin, A.; Sirotkin, Y. Assembling single-cell genomes and mini-metagenomes from chimeric MDA products. J. Comput. Biol. 2013, 20 , 714-737. [CrossRef] [PubMed]

72. Huelsenbeck, J.P.; Ronquist, F. MRBAYES: Bayesian inference of phylogenetic trees. Bioinformatics 2001, 17, 754-755. [CrossRef] [PubMed]

73. Weber, T.; Blin, K.; Duddela, S.; Krug, D.; Kim, H.U.; Bruccoleri, R.; Lee, S.Y.; Fischbach, M.A.; Müller, R.; Wohlleben, W. Antismash 3.0-A comprehensive resource for the genome mining of biosynthetic gene clusters. Nucleic Acids Res. 2015, 43, 237-243. [CrossRef]

74. Khan, M.S.; Gao, J.; Zhang, M.; Chen, X.; Du, Y.; Yang, F.; Xue, J.; Zhang, X. Isolation and characterization of plant growthpromoting endophytic bacteria Bacillus stratosphericus LW-03 from Lilium wardii. 3 Biotech 2020, 10, 305. [CrossRef] 
75. Gutierrez, C.K.; Matsui, G.Y.; Lincoln, D.E.; Lovell, C.R. Production of the phytohormone indole-3-acetic acid by estuarine species of the genus Vibrio. Appl. Environ. Microbiol. 2009, 75, 2253-2258. [CrossRef]

76. Ullah, S.; Qureshi, M.A.; Ali, M.A.; Mujeeb, F.; Yasin, S. Comparative potential of Rhizobium species for the growth promotion of sunflower (Helianthus annuus L.). Eurasian J. Soil Sci. 2017, 6, 189. [CrossRef] 